\title{
Modulation of $\gamma$-secretase by EVP-0015962 reduces amyloid deposition and behavioral deficits in Tg2576 mice
}

Kathryn Rogers ${ }^{1,8}$, Kevin M Felsenstein ${ }^{1,9}$, Lori Hrdlicka ${ }^{1}$, Zhiming Tu', Faris Albayya', Winnie Lee ${ }^{1,10}$, Sarah Hopp ${ }^{1,11}$, Mary-Jo Miller ${ }^{1,12}$, Darcie Spaulding ${ }^{1}$, Zhiyong Yang ${ }^{1,13}$, Hilliary Hodgdon', Scott Nolan ${ }^{1}$, Melody Wen ${ }^{1}$, Don Costa ${ }^{1}$, Jean-Francois Blain ${ }^{1}$, Emily Freeman ${ }^{1}$, Bart De Strooper ${ }^{2,3}$, Veerle Vulsteke ${ }^{2,3}$, Louise Scrocchi ${ }^{4,14}$, Henrik Zetterberg ${ }^{5,6}$, Erik Portelius ${ }^{5}$, Birgit Hutter-Paier ${ }^{7}$, Daniel Havas ${ }^{7}$, Michael Ahlijanian ${ }^{1,15}$, Dorothy Flood ${ }^{1}$, Liza Leventhal', Gideon Shapiro ${ }^{1,16}$, Holger Patzke', Richard Chesworth ${ }^{1,17}$ and Gerhard Koenig ${ }^{1 *}$

\begin{abstract}
Background: A hallmark of Alzheimer's disease is the presence of senile plaques in human brain primarily containing the amyloid peptides $A \beta_{42}$ and $A \beta_{40}$. Many drug discovery efforts have focused on decreasing the production of $A \beta_{42}$ through $\gamma$-secretase inhibition. However, identification of $\gamma$-secretase inhibitors has also uncovered mechanism-based side effects. One approach to circumvent these side effects has been modulation of $Y$-secretase to shift $A \beta$ production to favor shorter, less amyloidogenic peptides than $A \beta_{42}$, without affecting the overall cleavage efficiency of the enzyme. This approach, frequently called $\gamma$-secretase modulation, appears more promising and has lead to the development of new therapeutic candidates for disease modification in Alzheimer's disease.

Results: Here we describe EVP-0015962, a novel small molecule $\gamma$-secretase modulator. EVP-0015962 decreased $A \beta_{42}$ in $H 4$ cells $\left(I C_{50}=67 \mathrm{nM}\right)$ and increased the shorter $A \beta_{38}$ by 1.7 fold at the $I C_{50}$ for lowering of $A \beta_{42}$. $A \beta_{\text {Total, }}$ as well as other carboxyl-terminal fragments of amyloid precursor protein, were not changed. EVP-0015962 did not cause the accumulation of other $\gamma$-secretase substrates, such as the Notch and ephrin A4 receptors, whereas a $Y$-secretase inhibitor reduced processing of both. A single oral dose of EVP-0015962 (30 mg/kg) decreased $A \beta_{42}$ and did not alter $A \beta_{\text {Total }}$ peptide levels in a dose-dependent manner in Tg2576 mouse brain at an age when overt $A \beta$ deposition was not present. In Tg2576 mice, chronic treatment with EVP-0015962 (20 or 60 mg/kg/day in a food formulation) reduced $A \beta$ aggregates, amyloid plaques, inflammatory markers, and cognitive deficits.

Conclusions: EVP-0015962 is orally bioavailable, detected in brain, and a potent, selective $\gamma$-secretase modulator in vitro and in vivo. Chronic treatment with EVP-0015962 was well tolerated in mice and lowered the production of $A \beta_{42}$, attenuated memory deficits, and reduced $A \beta$ plaque formation and inflammation in Tg2576 transgenic animals. In summary, these data suggest that $\gamma$-secretase modulation with EVP-0015962 represents a viable therapeutic alternative for disease modification in Alzheimer's disease.
\end{abstract}

Keywords: $\gamma$-secretase, Modulation, NSAID, Cognition, Amyloid, Alzheimer's disease

\footnotetext{
* Correspondence: gkoenig@envivopharma.com

'EnVivo Pharmaceuticals, Inc, 500 Arsenal Street, Watertown, MA 02472, USA

Full list of author information is available at the end of the article
} 


\section{Background}

Alzheimer's disease (AD) is a progressive neurodegenerative disease, first described in 1907 [1]. Functional changes in this devastating disease include early memory deficits and later deficits affecting language, executive functioning, perception, and/or execution of complex motor patterns [2]. The neuropathology in $\mathrm{AD}$ is characterized by the presence of extracellular amyloid $(\mathrm{A} \beta)$ plaques and intracellular neurofibrillary tangles in the cerebral cortex, hippocampus, and amygdala, as well as other brain regions associated with memory and other domains of cognition [3]. The major constituents of the amyloid plaques are well established and include the 4 $\mathrm{kDa} A \beta$ peptides, primarily $A \beta_{42}$ and $A \beta_{40}$ [4-7]. There is considerable evidence suggesting that $A \beta_{42}$ is deposited early in the amyloid plaques and forms the seed for later deposition of other $A \beta$ species $[5,8]$. This evidence has suggested that an early and constant reduction in $A \beta_{42}$ in prodromal $A D$ might delay the onset or slow the progression of the disease by affecting the rate of plaque formation. $A \beta_{42}$ is derived from sequential processing of amyloid precursor protein (APP) by two proteases, $\beta$-site APP-cleaving enzyme (BACE) and $\gamma$-secretase $[9,10]$. Initially, BACE cleaves APP in its ectodomain, followed by $\gamma$-secretase cleavage in the APP transmembrane domain $[9,10]$, which ultimately produces a number of $A \beta$ peptides of various lengths [11]. Significantly, most familial AD mutations in the APP gene are found around the BACE or $\gamma$-secretase cleavage sites, and thus both BACE and $\gamma$-secretase have been targets for therapeutic intervention in $\mathrm{AD}[8,12]$.

$\gamma$-Secretase is a large complex composed of the four polypeptides: presenilin (PS-1 or PS-2), nicastrin (Nct), presenilin enhancer 2 (Pen-2), and anterior pharynxdefective 1 (Aph-1) [7]. $\gamma$-Secretase is responsible for the processing of more than 70 transmembrane proteins involved in normal cellular processes, including regulation of cell fate, cell adhesion, migration, neurite outgrowth, synaptogenesis, calcium homeostasis, transport of membrane proteins, and cell signaling [13,14]. Mutations in PS, the putative catalytic site of the $\gamma$-secretase complex, and in APP around the $\gamma$-secretase cleavage site, were shown to increase the ratio of $A \beta_{42} / A \beta_{40}$, strengthening support for $\gamma$-secretase inhibition for disease modification in $\mathrm{AD}[8,12]$. While inhibition of $\gamma$-secretase would produce the desired $A \beta$ reduction, it would also affect the proteolysis of its other substrates. The Notch receptor is one of these substrates [15], which is of particular interest since the inhibition of its proteolytic processing by $\gamma$ secretase inhibitors (GSIs) has been shown to result in the suppression of intestinal goblet cell differentiation and in immunosuppression [16]. Several GSIs have entered clinical trials in $\mathrm{AD}$, but unfortunately, have produced toxicities that are presumably mechanism-based. In particular, one compound (Semegacestat) produced drug-related rashes, lightening of hair color, skin cancer, and more importantly, worsening of cognition and the ability to perform activities of daily living [17-19]. These mechanism-based toxicities of GSIs have been attributed to the inhibition of Notch receptor processing and to the accumulation of the APP $\beta$ carboxyl-terminal fragment (CTF) $[16,19]$.

Neuroinflammation is another pathological hallmark of $\mathrm{AD}$ and is characterized by the presence of activated microglia and reactive astrocytes surrounding the amyloid plaques [20]. The question of whether the gliosis is causative or a compensatory result of the amyloid plaque deposition has been the subject of ongoing discussions and studies since it was first described [20,21]. For example, numerous retrospective studies associated a lower incidence of $\mathrm{AD}$ in patient populations that were prescribed non-steroidal anti-inflammatory drugs (NSAIDs) for other conditions [20]. It was therefore assumed that the NSAID therapy exerted positive effects on $\mathrm{AD}$ by reducing neurotoxic inflammation through the reduction of cyclooxygenase (COX) activities [20]. However, Weggen et al. [22,23] described a series of in vitro and in vivo studies utilizing several NSAIDs that produced a preferential reduction of $A \beta_{42}$ compared to $A \beta_{40}$. This reduction of $A \beta_{42}$ was accompanied by a concomitant increase in $A \beta_{38}$, a shorter, less amyloidogenic $A \beta$ peptide [12], rather than the inhibition of all carboxyl-terminal processing of APP [22,23]. Furthermore, they demonstrated that the effects of NSAIDs on the preferential reduction of $A \beta_{42}$ peptide levels were not linked to the inhibition of COX or other enzymes, but rather to a specific action on $\gamma$-secretase $[22,24]$. The shift in production of $A \beta$ peptides from the longer, toxic forms to the shorter, less toxic forms by NSAIDs has been termed $\gamma$-secretase modulation. This has sparked a flurry of activity directed at the development of compounds that modulate APP cleavage by $\gamma$-secretase and that could avoid the toxicities arising from the complete enzymatic inhibition of $\gamma$-secretase. Several recent publications have described second generation $\gamma$ secretase modulators (GSMs) [25-29] and Notch-sparing GSIs $[18,30]$. Here we present the in vitro and in vivo characterization of EVP-0015962, a potent, second generation GSM that specifically modulated production of $A \beta_{42}$ and $A \beta_{38}$ without affecting other $\gamma$-secretase substrates. In transgenic mice over-expressing APP, EVP0015962 was well tolerated following chronic dosing, produced reductions in amyloid plaque burden and neuroinflammation, and improved cognition.

\section{Results}

\section{EVP-0015962 selectively reduces the levels of $A \beta_{42}$} in vitro

In the course of a traditional drug discovery effort aimed at identifying novel compounds with GSM activity, EVP- 
0015962, (R)-2-(5-chloro-6-(2,2,2-trifluoroethoxy)-4' -(trifluoromethyl)biphenyl-3-yl)-3-cyclobutylpropanoic acid, was identified and characterized (Figure 1). Using human neuroglioma $\mathrm{H} 4$ cells, stably transfected with human wild type $\mathrm{APP}_{751}\left(\mathrm{H} 4-\mathrm{APP}_{751}\right.$ cells), EVP0015962 demonstrated a dose-dependent decrease in the levels of $A \beta_{42}$ after overnight incubation, while the levels of $\mathrm{A} \beta_{\text {Total }}$ remained unchanged up to $3 \mu \mathrm{M}$ (Figure $2 \mathrm{~A}$ ). The mean $\mathrm{IC}_{50}$ for $\mathrm{A} \beta_{42}$ was $67 \pm 5 \mathrm{nM}(\mathrm{n}=6)$. No effect was observed on $A \beta_{\text {Total }}$ until the concentration of EVP-0015962 reached levels at which cytotoxicity was observed in the MTS assay $\left(\mathrm{IC}_{50}=5.56 \pm 0.51 \mu \mathrm{M}, \mathrm{n}=\right.$ $6)$. The mean $\mathrm{EC}_{50}$ for $\mathrm{A} \beta_{38}$ was $33 \pm 4 \mathrm{nM}(\mathrm{n}=6)$. At the $\mathrm{IC}_{50}$ for $\mathrm{A} \beta_{42}$, the mean fold increase in $\mathrm{A} \beta_{38}$ was 1.7. The patterns of the $A \beta$ isoforms were also analyzed by matrix-assisted laser desorption/ionization-time-of-flight (MALDI-TOF) mass spectrometry after treatment of H4$\mathrm{APP}_{751}$ cells with DMSO or $700 \mathrm{nM}$ ( $\mathrm{IC}_{90}$ ) of EVP-0015962 (Figure 3A-B). The relative quantification of selected $\mathrm{A} \beta$ isoform peak heights for EVP-0015962 treatment compared with DMSO treatment showed that EVP-0015962 decreased $A \beta_{42}$ and $A \beta_{39}$ production, increased $A \beta_{38}$ and $A \beta_{33}$ production, and did not change $A \beta_{40}$ and $A \beta_{37}$ production.

The potency of EVP-0015962 was also evaluated in rat primary neocortical cultures. In these studies, EVP0015962 lowered the levels of $\mathrm{A} \beta_{42}$ with an average $\mathrm{IC}_{50}$ of $427 \pm 52 \mathrm{nM}(\mathrm{n}=4)$, while the $\mathrm{IC}_{50}$ values for the levels of $\mathrm{A} \beta_{1-\mathrm{x}}$ peptides and cytotoxicity were $>30 \mu \mathrm{M}$ $(\mathrm{n}=4)$ (Figure $2 \mathrm{~B})$. The mean $\mathrm{EC}_{50}$ for $\mathrm{A} \beta_{38}$ was $384 \pm$ $11 \mathrm{nM}(\mathrm{n}=2)$. At the $\mathrm{IC}_{50}$ for $\mathrm{A} \beta_{42}$, the mean fold increase in $\mathrm{A} \beta_{38}$ was 3.0. These results suggest that EVP0015962 acts as a typical GSM.

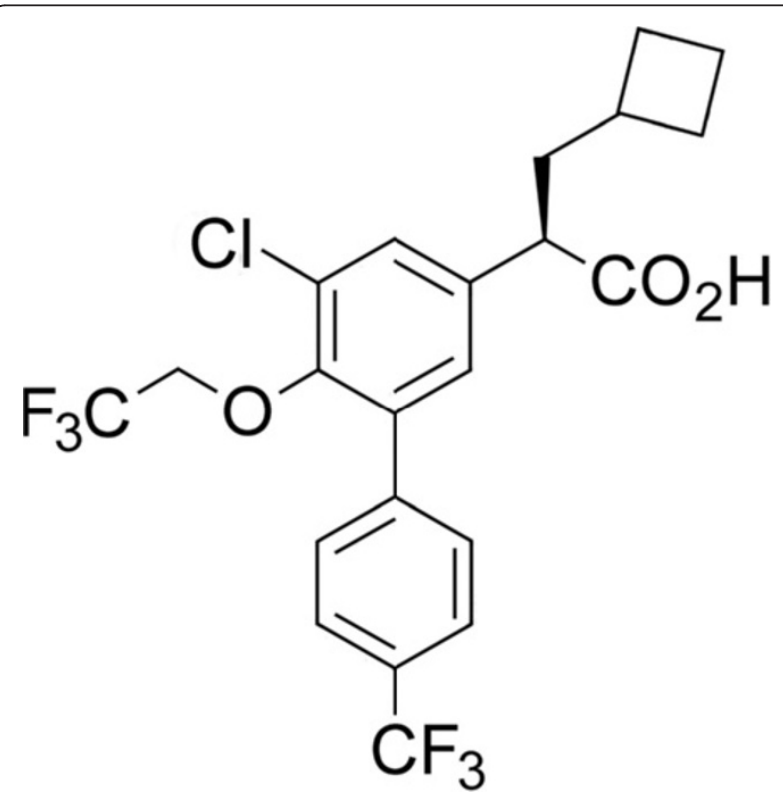

Figure 1 The chemical structure of EVP-0015962.
EVP-0015962 does not impair other $\gamma$-secretase cleavages

Most, if not all, $\gamma$-secretase substrates undergo ectodomain shedding; and the resulting CTFs are released from the membrane by $\gamma$-secretase [14]. This cleavage also leads to the production of intracellular domains (ICDs) of the $\gamma$ secretase substrates [14]. Inhibition or loss of $\gamma$-secretase has been shown to prevent the formation of these ICDs, and consequently to lead to the accumulation of CTFs of the $\gamma$-secretase substrates $[15,19,29-33]$. In the case of APP, the products of $\alpha$ - and $\beta$-secretase cleavages $(\alpha-$ and $\beta$ CTFs, respectively) are cleaved by $\gamma$-secretase to produce the APP intracellular domain (AICD). As shown in Figure $4 \mathrm{~A}$, in a cell-free system using reconstituted $\gamma$ secretase, up to $100 \mu \mathrm{M}$ of EVP-0015962 did not prevent the production of AICD from APP $\beta$-CTF, whereas treatment with the GSI, N-(N-(3,5-difluorophenacetyl)L-alanyl)-S-phenylglycine t-butyl ester (DAPT), almost completely abolished AICD production at $10 \mu \mathrm{M}$. In this cell-free assay, EVP-0015962 selectively reduced $\mathrm{A} \beta_{42}$ levels with an $\mathrm{IC}_{50}$ of $3.9 \mu \mathrm{M}$, without affecting the levels of $A \beta_{40}$ (Figure 2C-D). Recently, accumulation of APP $\beta$-CTF after chronic treatment with GSIs has been implicated in cognitive impairment [19]. We also showed that EVP-0015962 treatment of H4-APP 751 cells did not cause the accumulation of APP $\alpha$ - or $\beta$-CTFs at concentrations up to $10 \mu \mathrm{M}$, whereas the GSI LY-411,575 [16] led to their accumulation at a concentration as low as $1 \mathrm{nM}$ (Figure 4B). Full length APP was not altered by treatment with either EVP-0015962 or LY-411,575, consistent with published findings [27,30,33,34].

The inhibition of Notch intracellular domain (NICD) production is a well-characterized consequence of $\gamma$ secretase inhibition and has been linked to many of the toxicities associated with GSIs [16-18,31]. In HEK293 cells expressing Notch $\Delta$ E, EVP-0015962 did not affect levels of NICD produced or cell viability at concentrations up to 30 $\mu \mathrm{M}$ (Figure 4C-D). Finally, inhibition of the processing of one member of the ephrin (Eph) receptor family (EphA4) by GSIs was reported to inhibit dendritic spine formation in primary neurons [35]. The effects of EVP-0015962 and LY-411,175 on EphA4 CTF accumulation in rat primary neocortical cultures were assessed. Up to $10 \mu \mathrm{M}$ of EVP0015962 did not result in EphA4 CTF accumulation, whereas a concentration as low as $100 \mathrm{nM}$ of LY-411,175 led to EphA4 CTF accumulation (Figure 4E-F).

Single doses of EVP-0015962 reduce $A \beta_{42}$ in Tg2576 mice Acute dosing of EVP-0015962 was studied in male $\operatorname{Tg} 2576$ mice at 21 weeks, an age before the onset of $A \beta$ deposition in this transgenic APP over-expression model [36]. Four hours after administration of EVP-0015962 at 10 or $30 \mathrm{mg} /$ $\mathrm{kg}$, p.o., A $\beta$ peptides were extracted from brain using Tris buffered saline (TBS). Overall, $A \beta_{42}$ was significantly decreased by EVP-0015962 $(\mathrm{F}[2,9]=4.74, \mathrm{p}=0.039$, 

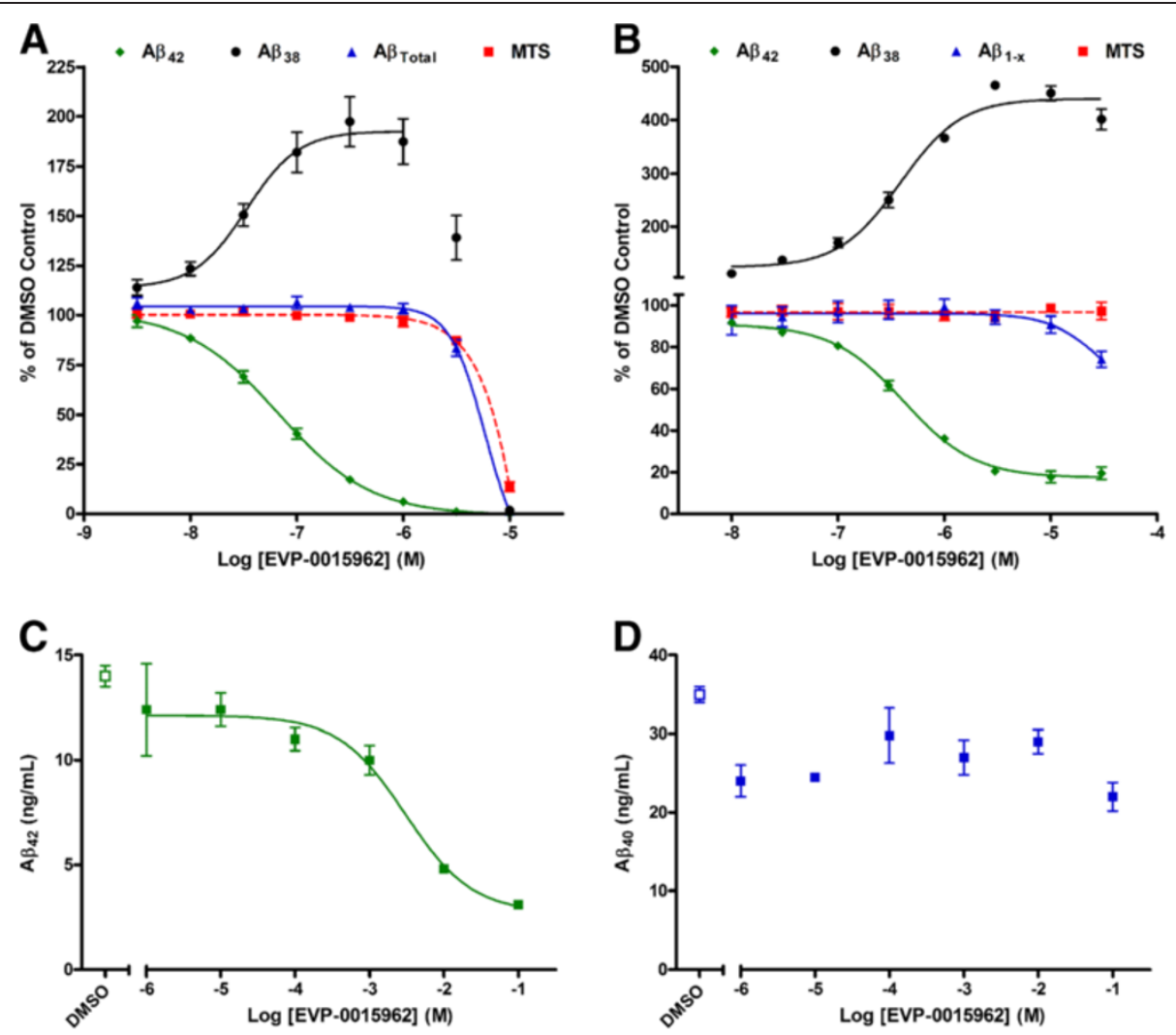

Figure 2 EVP-0015962 is a potent $\gamma$-secretase modulator. A. Concentration response curves for $A \beta_{42}, A \beta_{38}$, and $A \beta_{\text {Total }}$ determined by enzyme-linked immunosorbent assay (ELISA), and for cell viability in the H4-APP 751 cell assay. I $C_{50}=67 \mathrm{nM}$ for $A \beta_{42}$ and $E C_{50}=33 \mathrm{nM}$ for $A \beta_{38}$. For cell viability determined using the MTS assay, $I C_{50}=5.56 \mu \mathrm{M}$. IC $C_{50}>3 \mu \mathrm{M}$ for $A \beta_{\text {Total. }}$. For $A \beta_{38}$, the $E C_{50}$ value is determined for the concentration range of $3 \mathrm{nM}$ to $1 \mu \mathrm{M}$ of EVP-0015962, to avoid the portion of the curve where toxicity is observed. $\mathrm{N}=6$ independent experiments. B. Concentration response curves for $A \beta_{42}, A \beta_{38}$, and $A \beta_{1-x}$ determined by ELISA in media and for MTS from rat primary neocortical cultures. I $C_{50}=427 \mathrm{nM}$ for $A \beta_{42}$ and $E C_{50}=384 \mathrm{nM}$ for $A \beta_{38}$. IC $C_{50}>30 \mu \mathrm{M}$ for $\mathrm{A} \beta_{1-\mathrm{x}}$ and the MTS assay. $\mathrm{N}=4$ independent experiments for $A \beta_{42}$, $A \beta_{1-x}$ and MTS and 2 for $A \beta_{38}$. C. Concentration response curve for $A \beta_{42}$ in the cell-free assay. $I C_{50}=3.9 \mu M$. D. Concentration response curve for $A \beta_{40}$ in the cell-free assay. In the cell-free assays, $A \beta$ was determined by AlphaLisa in triplicate. All data are expressed as mean \pm standard error of the mean (SEM). For some data points, error bars are smaller than the sizes of the data points.

Figure 5A). The decreases compared to vehicle-treated mice were $22 \%$ for $10 \mathrm{mg} / \mathrm{kg}$ (NS) and $39 \%$ for $30 \mathrm{mg} / \mathrm{kg}$ of EVP-0015962 $(\mathrm{p}<0.05)$. A $\beta_{\text {Total }}$ remained unchanged by EVP-0015962 treatment $(\mathrm{F}[2,9]=0.085, \mathrm{p}=\mathrm{NS}$, Figure $5 \mathrm{~B})$.

\section{Chronic administration of EVP-0015962 is well tolerated and decreases brain $A \beta$ levels in Tg2576 mice}

The goal of the chronic study was to determine the effects of EVP-0015962 on AD-like pathology in $\mathrm{Tg} 2576$ mice when daily treatment was begun at 17-26 weeks of age, before visible $A \beta$ deposition is detected in this mouse model [36]. EVP-0015962 was administered to $\mathrm{Tg} 2576$ mice for 50 weeks in a food formulation. The concentrations of EVP-0015962 used in the food formulations were determined in pilot studies. Based on the minimum effective brain exposures to produce $A \beta$ reductions after single doses of 10 and $30 \mathrm{mg} / \mathrm{kg}$, p.o. in $\operatorname{Tg} 2576$ mice (1.3 and $4.3 \mu \mathrm{M}$, respectively at $4 \mathrm{~h}$ post-dosing), the compound concentrations of 20 and $60 \mathrm{mg} / \mathrm{kg} /$ day in the food formulations were selected. In C57BL/6 mice fed with the food formulations of 20 and $60 \mathrm{mg} / \mathrm{kg} /$ day for 3 or 7 days, the ranges of brain concentrations were 1.5-3.1 and 4.9$9.7 \mu \mathrm{M}$, respectively ( $\mathrm{n}=3$ studies). After 50 weeks, brain concentrations of EVP-0015962 in the chronically treated $\operatorname{Tg} 2576$ mice were $2.5 \pm 0.2$ and $8.3 \pm 0.6 \mu \mathrm{M}$ for 20 and $60 \mathrm{mg} / \mathrm{kg} /$ day, respectively. Thus, the brain concentrations of EVP-0015962 were within the expected range observed after short-term treatments and did not demonstrate accumulation or cytochrome P450 enzyme induction.

Body weights were tracked throughout the study to assess the long term tolerability of EVP-0015962 (Figure 6). All mice gained a significant amount of weight during the course of treatment $(\mathrm{p}<0.001)$, and there were no significant differences in body weight among the treatment groups at any time point during the study. These data indicated that chronic EVP-0015962 treatment was well tolerated. 


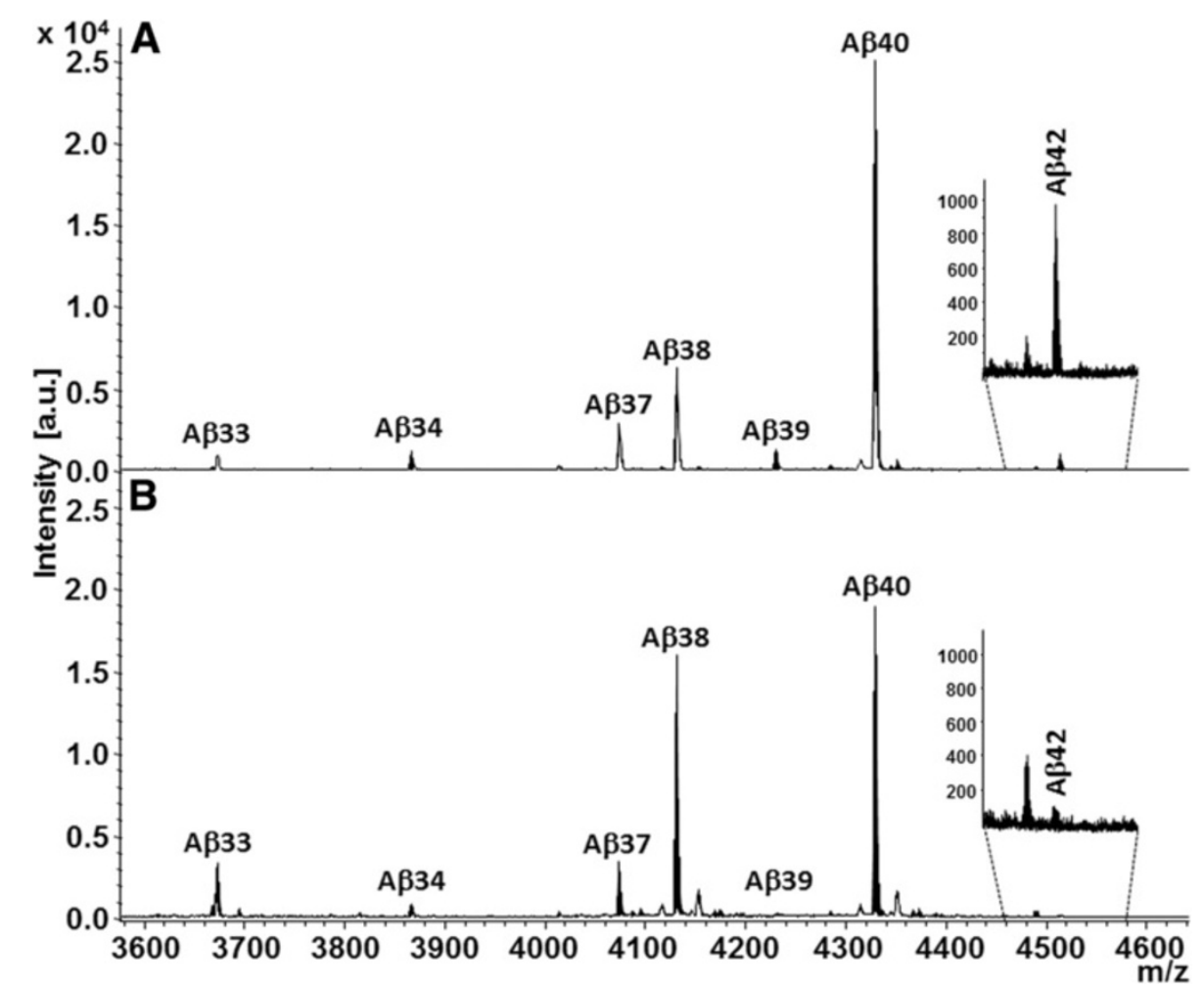

Figure 3 EVP-0015962 selectively affects processing of $\mathbf{A} \boldsymbol{\beta}$ isoforms. $\mathbf{A}$ and $\mathbf{B}$. Effect of EVP-0015962 treatment on production of $A \beta$ isoforms, measured by MALDI-TOF mass spectrometry. Mass spectra from H4-APP 751 cells treated with DMSO (A) and 700 nM EVP-0015962 (B). It should be noted that a relative quantification cannot be interpreted as a direct reflection of an absolute or relative abundance of a species since the ionization efficiency and hydrophobicity might be different for different $A \beta$ isoforms. $N=1$ experiment.

The effects of chronic EVP-0015962 treatment on sequentially extracted $\mathrm{A} \beta$ using TBS, Triton ${ }^{\circledR}-\mathrm{X}$, sodium dodecyl sulfate (SDS), and formic acid [37] were also evaluated. The results of the Triton ${ }^{\circledR}$-X fraction resembled those of the TBS fraction, and the results of the SDS fraction resembled those of the formic acid fraction. Therefore only the TBS (Figure 7A, C, E) and formic acid (Figure 7B, $D, F)$ fractions are described. $A \beta_{42}$ was significantly lowered in both the TBS soluble and formic acid extractable fractions (TBS, $\mathrm{F}[2,12]=12.3, \mathrm{p}=0.001$; formic acid, $F[2,12]=27.2, p<0.001$; Figure 7A-B). The percent reduction in $\mathrm{A} \beta_{42}$ in the TBS soluble fraction was $53 \%$ for $20 \mathrm{mg} / \mathrm{kg} /$ day $(\mathrm{p}<0.05)$ and $89 \%$ for $60 \mathrm{mg} / \mathrm{kg} /$ day ( $\mathrm{p}<0.001$ ). Similarly, formic acid extractable $A \beta_{42}$ was reduced for the 20 and $60 \mathrm{mg} / \mathrm{kg} /$ day doses by $53 \%$ and $86 \%$, respectively $(\mathrm{p}<0.001)$. In contrast, $\mathrm{A} \beta_{38}$ in the TBS soluble fraction was increased by treatment with EVP$0015962(\mathrm{~F}[2,12]=5.37, \mathrm{p}=0.022$, Figure $7 \mathrm{C})$. Treatment with $60 \mathrm{mg} / \mathrm{kg} /$ day of EVP-0015962 increased $A \beta_{38}$ by $78 \%$ $(\mathrm{p}<0.05)$, but $20 \mathrm{mg} / \mathrm{kg} /$ day did not produce a significant increase. In the formic acid extractable fraction, $A \beta_{38}$ was not significantly changed, despite a trend $(\mathrm{p}=0.055$ by t-test) towards a decrease in the $60 \mathrm{mg} / \mathrm{kg} /$ day group (Figure 7D). A $\beta_{\text {Total }}$ was unchanged in the TBS soluble fraction (Figure 7E), but was reduced in the formic acid extractable fraction $(\mathrm{F}[2,12]=8.59, \mathrm{p}=0.005$, Figure $7 \mathrm{~F})$. The reductions were $49 \%(\mathrm{p}<0.05)$ and $64 \%(\mathrm{p}<0.01)$ at 20 and $60 \mathrm{mg} / \mathrm{kg} /$ day of EVP-0015962, respectively. During the chronic study, $A \beta$ peptide levels were evaluated after 11 and 28 weeks of dosing in additional Tg2576 mice. A $\beta_{42}$ peptide levels from the TBS soluble and insoluble fractions increased exponentially in mice on the control diet (Figure 7G-H). Treatment with $60 \mathrm{mg} / \mathrm{kg} /$ day of EVP0015962 for 50 weeks prevented the dramatic increase in both soluble and insoluble $A \beta_{42}$ that is normally associated with $A \beta$ deposition in this mouse model. The lower dose of EVP-0015962 was partially effective in preventing the increase in $A \beta_{42}$ over the course of the 50-week treatment.

Aggregated $A \beta$, measured by the Amorfix aggregated $\mathrm{A} \beta$ assay, was detectable in all groups of $\operatorname{Tg} 2576$ mice and was reduced by 50 weeks of treatment with EVP$0015962(\mathrm{H}[3]=10.28, \mathrm{p}=0.006$, Figure $8 \mathrm{~A})$. There was a significant reduction in aggregated $A \beta$ of $73 \%$ in the group receiving $60 \mathrm{mg} / \mathrm{kg} /$ day of EVP-0015962 compared to the control diet group $(\mathrm{p}<0.01)$.

Brain samples were also analyzed by Western blotting to determine whether 50 weeks of treatment with EVP0015962 resulted in accumulation of APP CTFs. There 

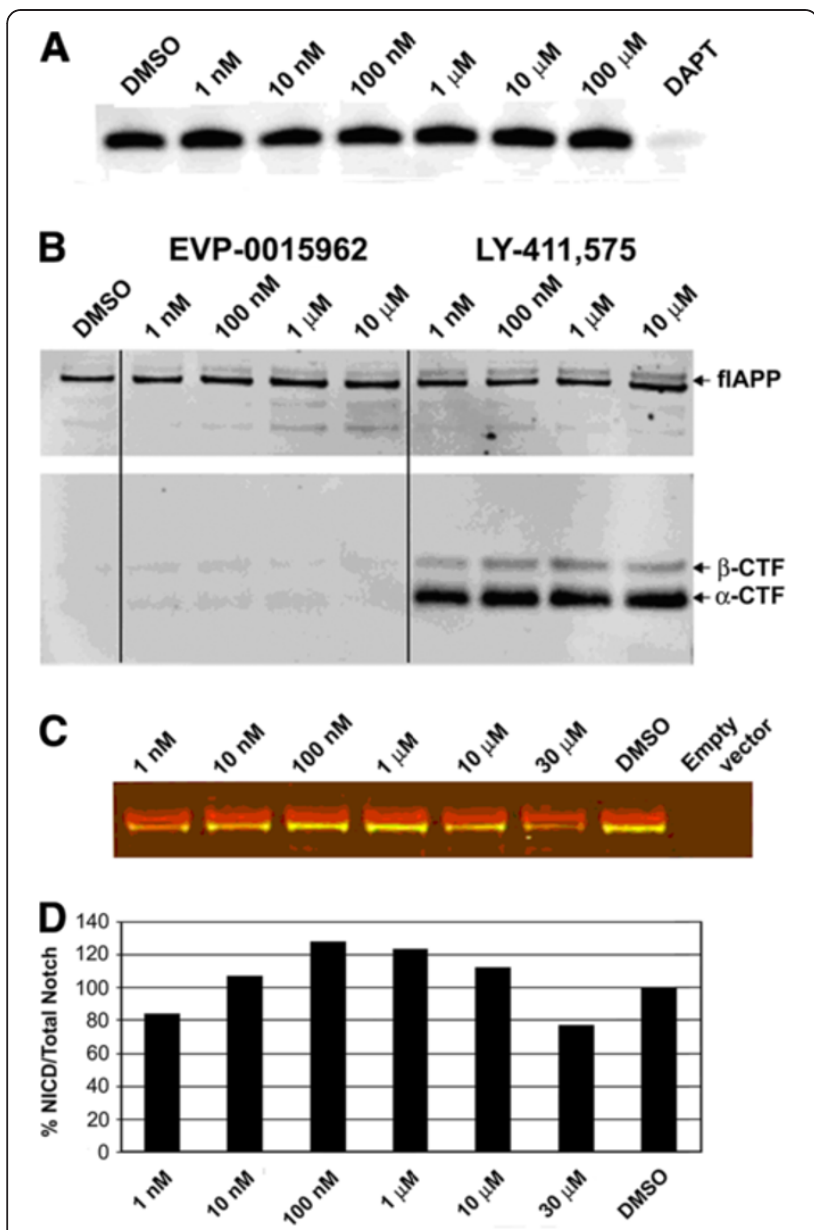

E
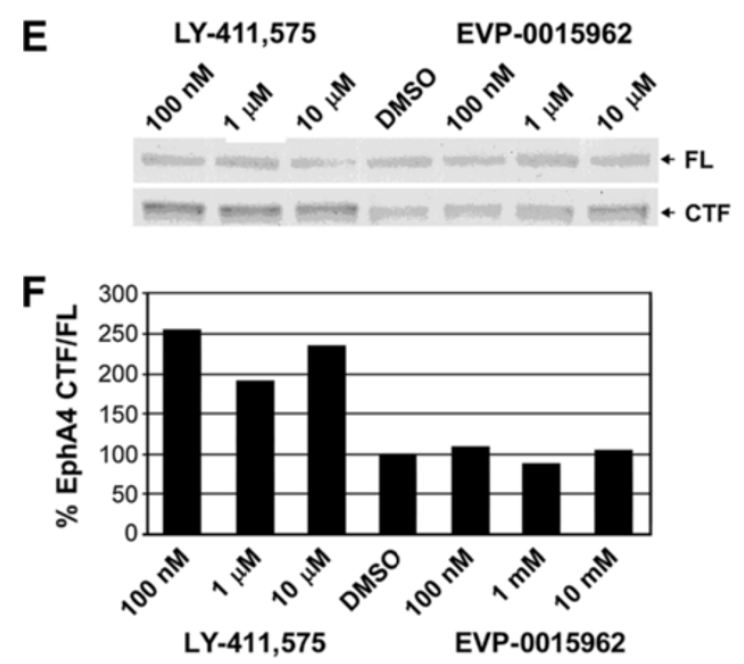

Figure 4 EVP-0015962 does not alter processing of APP or other $\boldsymbol{\gamma}$-secretase substrates. A. Effect of EVP-0015962 treatment on the $\varepsilon$-cleavage of APP $\beta$-CTF, measured in a cell-free assay with Aph1 $A_{L}$ containing $Y$-secretase complexes. Representative Western blot of AICD fragments, for EVP-0015962 (1 nM to $100 \mu \mathrm{M}$ ) and DAPT $(10 \mu M)$. DMSO is the control lane. $N=2$ experiments. B. Full length APP (fIAPP), a-CTF, and $\beta$-CTF from H4-APP 751 cell lysates, analyzed by Western blot after a 16-h treatment with $1 \mathrm{nM}$ to $10 \mu \mathrm{M}$ of LY-411,575 or EVP-0015962. $N=1$ experiment. C and D. Effect of EVP-0015962 treatment (1 nM to $30 \mu \mathrm{M}$ ) on the S3 cleavage of Notch $\Delta$ E to form NICD, measured in transfected HEK293 cells. C. Representative Western blot of NICD fragments fluorescently labeled with cleaved Notch1 antibody (green) and Myc-tagged antibody (red). The NICD fragments are detected as yellow in an overlay of both antibodies. DMSO is the control lane and Empty vector is a lysate from cells without the Notch $\Delta \mathrm{E}$ construct. D. NICD intensity histogram corresponding to the Western blot in E. NICD is quantified as a percentage of total Notch. $\mathrm{N}=2$ experiments. $\mathbf{E}$ and F. Effect of $24 \mathrm{~h}$ of treatment with $100 \mathrm{nM}$ to $10 \mu \mathrm{M}$ of LY-411,575 or EVP-0015962 on the production of EphA4 CTF in cell lysates from rat primary neocortical cultures. E. Western blot of full length (FL) EphA4 (upper band) and EphA4 CTF (lower band). F. Ratio of EphA4 CTF to full length EphA4 corresponding to the Western blot in E. $N=1$ experiment.

were no increases in the levels of full length APP, $\beta$-CTF, and $\alpha$-CTF (Figure $8 \mathrm{~B}-\mathrm{C}$ ) for mice at either dose compared to mice on control diet. On the other hand, total $A \beta$ was significantly and dose dependently decreased by EVP0015962 treatment $(F[2,7]=27.5, \mathrm{p}<0.001$, Figure 8B, $\mathrm{D})$. Compared to $\operatorname{Tg} 2576$ mice on the control diet, the reductions were $42 \%(\mathrm{p}<0.01)$ and $81 \%(\mathrm{p}<0.001)$ for the 20 and $60 \mathrm{mg} / \mathrm{kg} /$ day groups, respectively. This suggested that while long-term treatment with EVP-0015962 decreased $A \beta$ levels, it did not inhibit the overall processing of APP CTFs by $\gamma$-secretase in vivo.

\section{Chronic treatment with EVP-0015962 inhibits plaque formation and inflammation}

Histological evaluation of amyloid plaques was performed with ThioflavinS fluorescence to visualize compact cores specifically and with 6E10 antibody immunostaining for the compact cores and the surrounding halo of more diffuse $A \beta$ (Table 1, Figure 9A-B). Tg2576 mice treated for 50 weeks with EVP-0015962 showed a significant reduction in percent area and number of amyloid plaques in the hippocampus by immunostaining with 6E10 antibody (percent area, $\mathrm{F}[2,18]=4.13, \mathrm{p}=0.033$; number, $\mathrm{F}[2,18]=$ $4.79, p=0.022)$. There was no effect on the mean plaque size. These reductions were seen for both the 20 and 60 $\mathrm{mg} / \mathrm{kg} /$ day groups $(\mathrm{p}<0.05)$. In the neocortex, the reductions in percent area and number of 6E10-positive amyloid plaques were trends (percent area, $\mathrm{F}[2,18]=2.60, \mathrm{p}=$ 0.102; number, $\mathrm{F}[2,18]=3.51, \mathrm{p}=0.052$ ). In addition, EVP-0015962 significantly reduced the percent area and number of ThioflavinS-positive amyloid plaque cores in the hippocampus (percent area, $F[2,18]=8.13, \mathrm{p}=0.003$; 

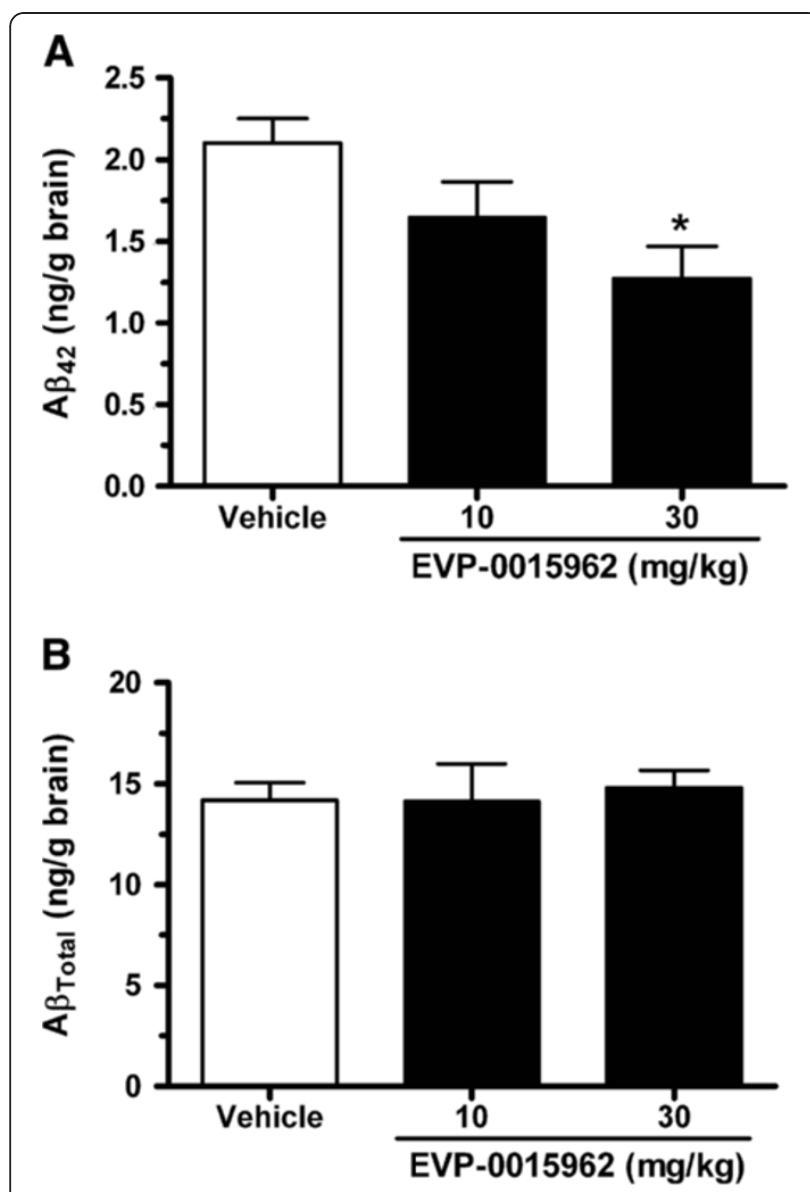

Figure 5 In Tg2576 mice, a single dose of EVP-0015962 decreases brain $A \beta_{42}$ without altering $A \beta_{\text {Total }}$. Brain concentrations of $A \beta_{42}(\mathbf{A})$ and $A \beta_{\text {Total }}(\mathbf{B})$, measured $4 \mathrm{~h}$ after 10 or $30 \mathrm{mg} / \mathrm{kg}$, p.o. of EVP-0015962 by sandwich ELISAs, following TBS extraction. Graphs illustrate mean + SEM, N $=4$ per group. Difference from the vehicle-treated group: ${ }^{*} \mathrm{p}<0.05$ (1-way ANOVA, post-hoc Newman-Keuls test).

number, $F[2,18]=4.31, \mathrm{p}=0.029)$. The reductions in the hippocampus reached significance for both the 20 and $60 \mathrm{mg} / \mathrm{kg} /$ day groups for percent area $(\mathrm{p}<0.01)$ and number $(\mathrm{p}<0.05)$ of plaque cores. In the neocortex, the percent area and number of ThioflavinS-positive plaque cores were also significantly reduced (percent area, $\mathrm{F}[2,18]=5.20, \mathrm{p}=0.017$; number, $\mathrm{F}[2,18]=3.57$, $\mathrm{p}=0.049)$. At the high dose, percent area of plaque cores was significantly reduced in the neocortex ( $\mathrm{p}<$ 0.05 ), while plaque number trended lower ( $\mathrm{t}$-test, $\mathrm{p}=$ 0.054). The size of ThioflavinS-positive plaque cores trended lower in the neocortex and hippocampus after EVP-0015962 treatment (neocortex, $\mathrm{F}[2,18]=3.53, \mathrm{p}=$ 0.051 ; hippocampus, $\mathrm{F}[2,18]=2.50, \mathrm{p}=0.110)$. In the neocortex, the post hoc test for plaque core size was nevertheless significant for the comparison of the control diet group with the group treated with $60 \mathrm{mg} / \mathrm{kg} /$ day of EVP-0015962 ( $<<0.05)$.
Concurrent with the reduction in amyloid pathology, reactive astrocytosis, visualized by immunostaining with an antibody against glial fibrillary acidic protein (GFAP), trended lower in the neocortex $(\mathrm{F}[2,18]=2.72, \mathrm{p}=0.093$; Table 1, Figure 9C-D). By t-test, the $60 \mathrm{mg} / \mathrm{kg} /$ day group was significantly lower than the control diet group for percent area of reactive astrocytes in the neocortex $(\mathrm{p}=0.038)$. Activated microglia, immunostained with an antibody against CD11b, trended lower in both the neocortex and hippocampus (neocortex, $\mathrm{F}[2,18]=2.57$, $\mathrm{p}=0.104$; hippocampus, $\mathrm{F}[2,18]=3.37, \mathrm{p}=0.057$; Table 1 , Figure $9 \mathrm{C}-\mathrm{D})$. By t-test, the reduction in activated microglia reached significance in a comparison of $60 \mathrm{mg} / \mathrm{kg} /$ day and control diet groups in the hippocampus $(\mathrm{p}=0.046)$, but was a trend in the neocortex $(p=0.069)$.

\section{Contextual fear conditioning deficits are reversed by chronic treatment with EVP-0015962}

Contextual fear conditioning (CFC) is an important behavioral assay for studying learning and memory related to hippocampal function [38], and has shown deficits in Tg2576 mice that are reversed by both GSIs and GSMs $[39,40]$. Beginning at 19-22 weeks of age, $\operatorname{Tg} 2576$ mice were treated with EVP-0015962 and Tg2576 and WT mice were treated with control diet for 11 weeks. In the CFC assay there was an overall significant effect on percent freezing behavior $(\mathrm{F}[3,46]=5.95, \mathrm{p}=0.002$, Figure $10 \mathrm{~A})$. In post hoc analysis, a cognitive deficit (decrease in percent freezing behavior) was detected at 30-33 weeks of age in the Tg2576 mice on control diet compared to WT mice on control diet $(\mathrm{p}<0.01)$. This genotype-associated deficit in the $\operatorname{Tg} 2576$ mice was reversed by treatment with 20 or $60 \mathrm{mg} / \mathrm{kg} /$ day of EVP-0015962 ( $<$ < 0.01).

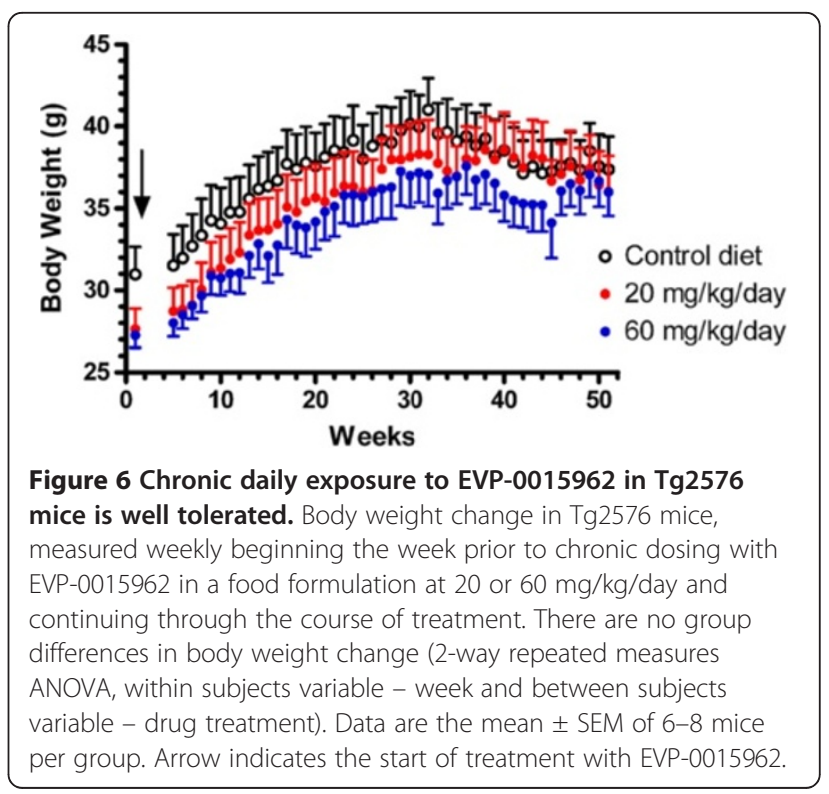



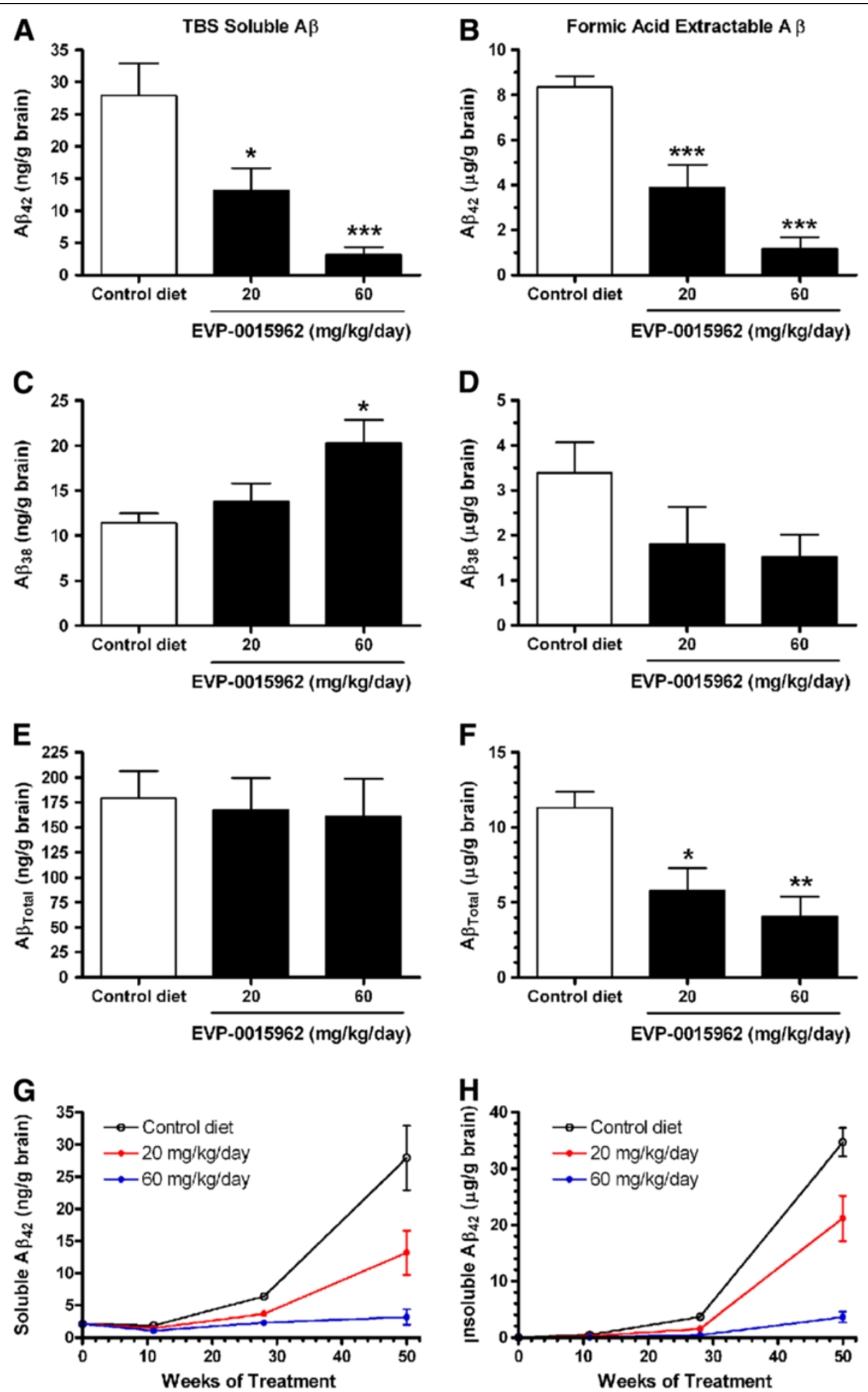

Figure 7 Chronic daily exposure to EVP-0015962 in Tg2576 mice reduces A $\beta$ peptide levels. A-F. TBS soluble (A, C, E) and formic acid extractable (B, D, F) A $\beta$ peptide levels determined by ELISA from the brains of Tg2576 mice after 50 weeks of treatment with EVP-0015962 for $A \beta_{42}(\mathbf{A}-\mathbf{B}), A \beta_{38}(\mathbf{C}-\mathbf{D})$, and $A \beta_{\text {Total }}(\mathbf{E}-\mathbf{F}) . N=5$ mice per group. Differences from the control diet group: ${ }^{*} p<0.05,{ }^{* *} p<0.01,{ }^{* * *} p<0.001$ (1-way ANOVA, post-hoc Newman-Keuls test). G-H. $A \beta_{42}$ peptide levels measured at the beginning of treatment and after 11, 28, and 50 weeks of treatment with EVP-0015962, showing the time course of accumulation of $A \beta_{42}$. G. TBS soluble $A \beta_{42}$. H. Insoluble $A \beta_{42}$. At 11 and 28 weeks, insoluble $A \beta_{42}$ was extracted with only formic acid. At 0 and 50 weeks, the 4-step procedure was used, and the insoluble fraction is the sum of the $A \beta_{42}$ extracted with Triton $^{\circledR}-X, S D S$, and formic acid. $N=4-6$ mice per group and time point. Graphs illustrate mean \pm SEM. 


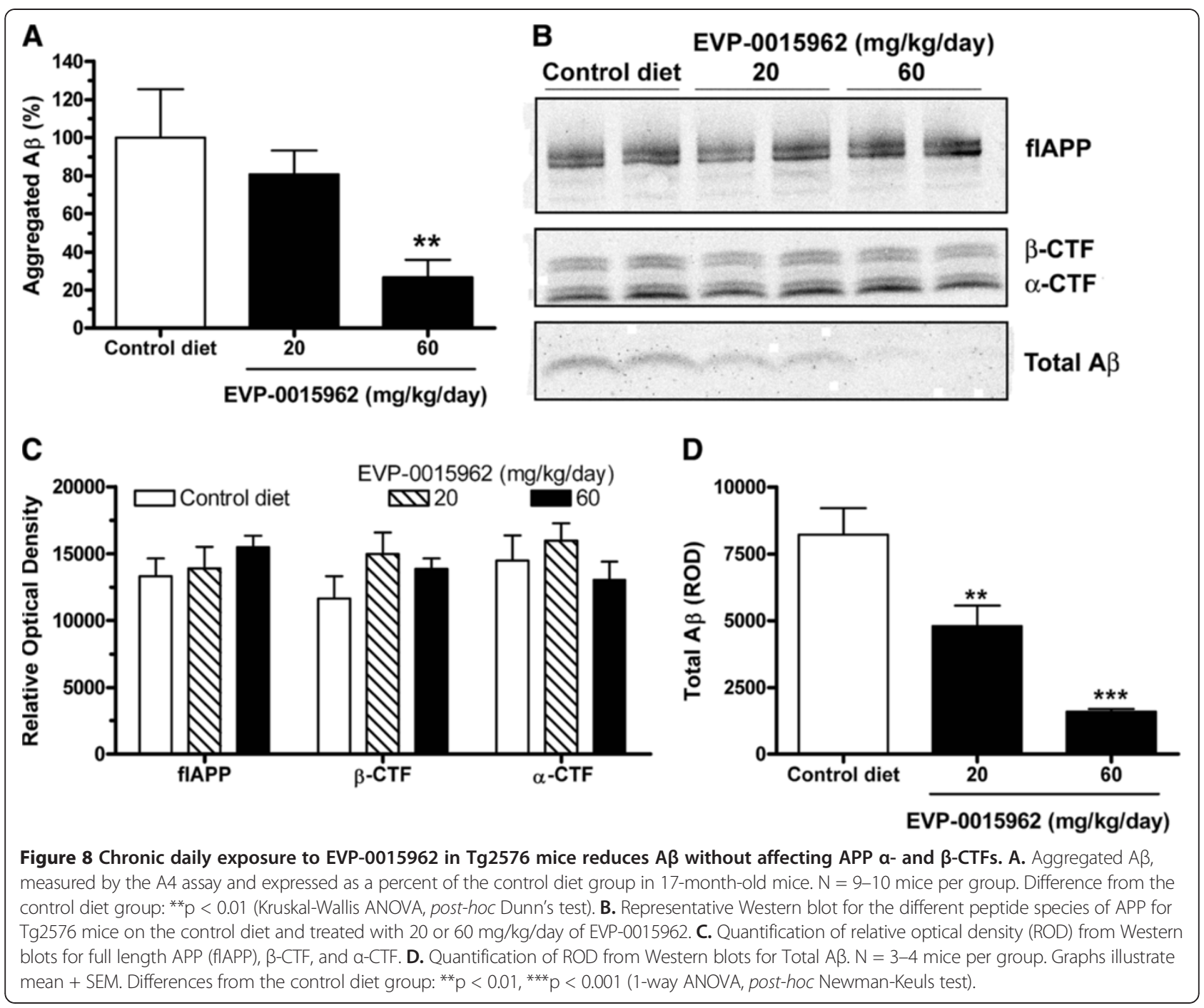

A satellite group of Tg2576 and WT mice at 30 weeks of age received a single administration of EVP-0015962 (30 $\mathrm{mg} / \mathrm{kg}$, p.o.) on day $1,3 \mathrm{~h}$ prior to the training session, in order to evaluate whether there were any acute effects of EVP-0015962 treatment on cognition. Overall, there were group differences in percent freezing $(\mathrm{F}[3,48]=5.67, \mathrm{p}=$ 0.002 , Figure $10 \mathrm{~B})$. There was a significant genotypeassociated deficit in the Tg2576 mice compared with WT mice for the vehicle-treated mice and EVP-0015962treated mice ( $\mathrm{t}$-tests, $\mathrm{p}<0.05$ ). However, neither the Tg2576 nor WT mice treated with $30 \mathrm{mg} / \mathrm{kg}$, p.o. of EVP0015962 showed an increase in percent freezing compared to their respective vehicle-treated groups.

\section{Discussion}

The presence of neuroinflammation in $\mathrm{AD}$ and the seemingly positive effects of chronic NSAID usage on the reduction of the risk of developing $\mathrm{AD}$ in retrospective epidemiological studies $[20,41]$ suggested that NSAIDs might be operating via the inhibition of $\mathrm{COX}$ or activation of the peroxisome proliferator-activated receptor $\gamma$. Indeed, studies in Tg2576 mice generated evidence to support this hypothesis. Tg2576 mice that were fed a diet of $375 \mathrm{ppm}$ of ibuprofen for 4-6 months, showed a marked decrease in amyloid plaque load, as well as in inflammatory mediators, such as interleukin-1 $\beta$, GFAP, and markers of microglial activation $[42,43]$. However, subsequent mechanistic studies suggested that certain NSAIDs were able to produce a preferential reduction of $A \beta_{42}$, without altering the levels of other $A \beta$ peptides, presumably through a direct modulation of $\gamma$-secretase $[22,23,44]$. The result of $\gamma$-secretase modulation by NSAIDs was an overall shift in the $A \beta_{42} / A \beta_{40}$ ratio, with an accompanying increase in the shorter $A \beta_{38}$, both of which were not correlated to COX activity or the activity of other enzymes inhibited by NSAIDs [22-24].

The first generation GSM to be tested in the clinic was Flurizan $^{\text {тм }}$, the $R$ enantiomer of the racemate NSAID, flurbiprofen $[44,45]$. Flurizan ${ }^{\mathrm{TM}}$ has the classic 
Table 1 Mean ( \pm sem) percent of control after chronic of treatment with EVP-0015962 at 20 or $60 \mathrm{mg} / \mathrm{kg} / \mathrm{day}$

\begin{tabular}{|c|c|c|c|c|c|c|}
\hline \multirow{3}{*}{$\begin{array}{l}\text { Stain and pathology } \\
\text { Parameter }\end{array}$} & \multicolumn{3}{|c|}{ Neocortex } & \multicolumn{3}{|c|}{ Hippocampus } \\
\hline & \multirow{2}{*}{$\begin{array}{c}\text { Control } \\
\text { diet }\end{array}$} & \multicolumn{2}{|c|}{ EVP-0015962 (mg/kg/day) } & \multirow{2}{*}{$\begin{array}{c}\text { Control } \\
\text { diet }\end{array}$} & \multicolumn{2}{|c|}{ EVP-0015962 (mg/kg/day) } \\
\hline & & 20 & 60 & & 20 & 60 \\
\hline \multicolumn{7}{|c|}{ 6E10 immunostaining of $A \beta$ plaque pathology } \\
\hline Percent area & $100(10.8)$ & $69.2(9.7)$ & $65.3(16.3)$ & $100(10.8)$ & $62.1(13.2)^{*}$ & $53.1(15.2)^{*}$ \\
\hline Number $/ \mathrm{mm}^{2}$ & $100(7.9)$ & $65.2(8.8)$ & $71.3(15.0)$ & $100(9.7)$ & $61.0(12.2)^{*}$ & $53.9(16.8)^{*}$ \\
\hline Size $\left(\mu m^{2}\right)$ & $100(6.5)$ & $105.5(8.8)$ & $88.5(5.4)$ & $100(16.4)$ & $99.4(15.7)$ & $104.1(11.6)$ \\
\hline \multicolumn{7}{|c|}{ ThioflavinS staining of $A \beta$ plaque pathology } \\
\hline Percent area & $100(18.0)$ & $64.3(14.3)$ & $29.9(7.3)^{*}$ & $100(14.7)$ & $40.7(16.9)^{* *}$ & $27.3(6.5)^{* *}$ \\
\hline Number $/ \mathrm{mm}^{2}$ & $100(12.4)$ & $64.3(8.0)$ & $59.6(14.1)$ & $100(12.7)$ & $55.2(15.6)^{*}$ & $50.7(12.8)^{*}$ \\
\hline Size $\left(\mu m^{2}\right)$ & $100(8.5)$ & $87.8(12.2)$ & $58.1(10.6)^{*}$ & $100(6.8)$ & $56.5(16.3)$ & $58.9(27.0)$ \\
\hline \multicolumn{7}{|c|}{ GFAP immunostaining of reactive astrocytes } \\
\hline Percent area & $100(12.5)$ & $95.8(14.5)$ & $61.6(7.6)$ & $100(9.0)$ & $95.8(7.7)$ & $87.2(9.7)$ \\
\hline \multicolumn{7}{|c|}{ CD11b immunostaining of activated microglia } \\
\hline Percent area & $100(12.8)$ & $86.3(5.0)$ & $66.2(7.7)$ & $100(12.1)$ & $69.8(9.2)$ & $61.8(10.7)$ \\
\hline
\end{tabular}

${ }^{*} \mathrm{p}<0.05$, ${ }^{* *} \mathrm{p}<0.01$ compared with Tg2576 mice on control diet by 1-way ANOVAs and post-hoc Newman-Keuls tests.

$\mathrm{N}=9$ mice in the control diet group and 6 in the EVP-0015962 treatment groups.

GSM signature of lowering $A \beta_{42}$ without affecting the total amount of $\mathrm{A} \beta$ peptides. However, Flurizan ${ }^{\text {тм }}$ was a relatively weak GSM $\left(\mathrm{IC}_{50}>300 \mu \mathrm{M}\right.$ for $\mathrm{A} \beta_{42}$ [46]), with low brain concentrations in animals and man, and was subsequently withdrawn from clinical evaluation due to the lack of efficacy in a large phase III trial [47]. More recently, second generation GSMs from multiple chemical classes have been reported, which have improved potency and brain concentrations [25-29,44,48]. In the current study, we have characterized EVP-0015962, a potent small molecule compound, which has a substantially improved potency $(4,500$-fold) and pharmacological profile compared with Flurizan ${ }^{\mathrm{TM}}$. EVP-0015962 had a measured LogD of 3.88 and was present in the brain at 1.3 to $4.3 \mu \mathrm{M}$ after single oral doses of 10 and $30 \mathrm{mg} / \mathrm{kg}$, respectively. Moreover, we have demonstrated that $\gamma$-secretase activity is modulated by EVP-0015962 to selectively decrease $A \beta_{42}$ levels $\left(\mathrm{IC}_{50}=67 \mathrm{nM}\right)$ in $\mathrm{H} 4-\mathrm{APP}_{751}$ cells, and increase levels of the shorter $\mathrm{A} \beta_{38}$ peptide $\left(\mathrm{EC}_{50}=33 \mathrm{nM}\right)$, without a change in $\mathrm{A} \beta_{\text {Total }}$ (composed primarily of $A \beta_{40}$ [7]) or in $A \beta$ peptides of other lengths. These changes in the levels of $A \beta_{42}$ and $\mathrm{A} \beta_{38}$ peptides were seen in the in vitro assay systems, as well as in vivo in Tg2576 mice after acute treatment. The lack of overall change in $A \beta$ peptide levels and the increase in $A \beta_{38}$ by EVP-0015962 suggest selective modulation, rather than inhibition of the $\gamma$-secretase enzyme complex, similar to the mechanism of action of other GSMs with similar chemotypes [48]. In contrast, GSMs of other chemical classes do reduce $A \beta_{40}$ peptide levels, albeit with a higher $\mathrm{IC}_{50}$ than that for $\mathrm{A} \beta_{42}$, suggesting that they might function differently than EVP$0015962[29,48]$.
We further substantiated the modulatory effects of EVP-0015962 by determining whether the compound inhibited the $\mathrm{S} 3 / \varepsilon$-cleavage activity of the $\gamma$-secretase complex at its other natural substrates. EVP-0015962 did not inhibit the ability of $\gamma$-secretase to generate AICD and NICD in vitro. As expected from a lack of effect on AICD formation, no accumulation of APP $\alpha$ - and $\beta$-CTFs was observed in the presence of EVP0015962 either in vitro or in vivo. EVP-0015962 also did not cause the accumulation of EphA4 CTF. The lack of effect on the processing of other $\gamma$-secretase substrates is thus also consistent with $\gamma$-secretase modulation. This suggests that EVP-0015962 may avoid the mechanismbased side effects that have been previously associated with GSIs (e.g., intestinal goblet cell hyperplasia and immunosuppression due to inhibition of Notch receptor processing and cognitive impairment due to the accumulation of APP $\beta$-CTF) $[16,19]$. Furthermore, in our longitudinal efficacy study in $\operatorname{Tg} 2576$ mice, in which we observed a significant reduction of $A \beta_{42}$, we found no evidence of effects on intestinal goblet cells or on any other organ system examined in satellite animals treated with up to $60 \mathrm{mg} / \mathrm{kg} /$ day of EVP-0015962 for 11 weeks. The tolerability of EVP-0015962 was also demonstrated by the similar weight gains at the 20 and $60 \mathrm{mg} / \mathrm{kg} /$ day doses of EVP-0015962, when compared to Tg2576 mice on the control diet for 50 weeks. In addition, when survival was examined after 50 weeks of treatment, $25 \%$ of the high $(60 \mathrm{mg} / \mathrm{kg} /$ day $)$ dose group was lost compared to $27 \%$ of the control diet group. The observed mortality rates were consistent with the $>20 \%$ rates reported for this transgenic model by the supplier (http://www.taconic. com/wmspage.cfm?parm1=2646). 


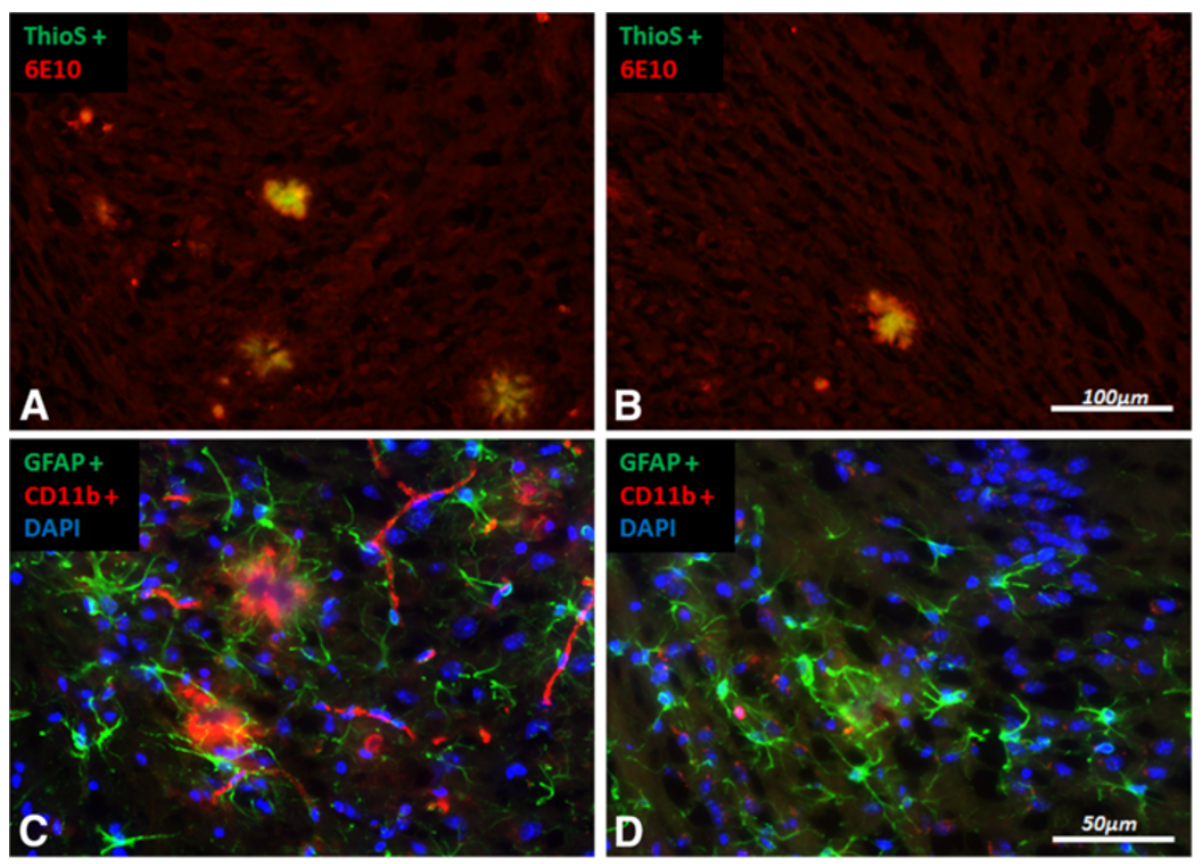

Figure 9 Chronic daily exposure to EVP-0015962 in Tg2576 mice reduces A $\beta$ deposition and reactive gliosis. Representative sections illustrating staining of amyloid plaques with Thioflavins (green) and by immunohistochemistry (6E10, red) in the subiculum of the hippocampus from Tg2576 mice fed either a control diet (A) or treated with 20 mg/kg/day of EVP-0015962 (B). Representative sections illustrating immunohistochemical staining of reactive astrocytes (GFAP, green) and activated microglia (CD11b, red) in the subiculum from Tg2576 mice, fed either a control diet (C) or treated with 60 mg/kg/day of EVP-0015962 (D). Nuclei are stained with 4',6-diamidino-2-phenylindole (DAPI, blue). In C, amyloid deposits are visualized by the presence of interspersed fine microglial processes and are surrounded by activated microglia and in turn by GFAP-positive astrocytes.

One of the major goals of the longitudinal study was to determine the effects of EVP-0015962 on AD-like pathology in a transgenic mouse model. The Tg2576 mouse model expresses high levels of APP and A $\beta$ with a transgene containing human APP695 bearing the Swedish mutation (K670N/M671L) behind the hamster prion protein gene promoter [36]. One significant advantage of the Tg2576 model is that diffuse and neuritic plaques begin to appear at approximately 6-7 months and, along with extractable $A \beta$, increase with age [37]. Furthermore, these age-related changes are coincident with the appearance of cognitive deficits [36,49], suggesting that these mice are a useful tool for studies of A $\beta$ modifying therapies.

In an interim assessment, after 11 weeks of chronic treatment with EVP-0015962, we examined the behavioral effects of GSM treatment. Studies have shown that treatments that lower $A \beta$ can restore cognitive function in these animals $[39,40]$. In the CFC assay, which is primarily hippocampal dependent [38], the $\operatorname{Tg} 2576$ mice displayed the expected cognitive deficit in contextual memory at 30-33 weeks of age. Importantly, the cognitive deficit was reversed and/or prevented at both dose levels following 11 weeks of treatment with EVP-0015962. Separate groups of Tg2576 and WT mice received a single administration of EVP-0015962 (30 mg/kg, p.o. on day 1, $3 \mathrm{~h}$ prior to training) in order to evaluate the acute effects of EVP0015962 treatment on CFC. Overall, differences between the genotypes were observed in this study (i.e., a genotypeassociated deficit in the $\operatorname{Tg} 2576$ mice). However, acute dosing with EVP-0015962 did not reverse this deficit. This is in contrast to the report that $100 \mathrm{mg} / \mathrm{kg}$, p.o. of the GSI DAPT, administered $3 \mathrm{~h}$ before training in $\operatorname{Tg} 2576$ mice, lowered $A \beta$ levels and rapidly improved the CFC cognitive deficit [39]. The WT mice, however, did not have improved CFC performance after DAPT treatment, suggesting that the effect was due to $A \beta$ lowering, rather than to a general cognitive enhancing effect, as observed with rolipram in the same study. It is unclear by what mechanism a GSI improved cognition acutely and why the GSM EVP0015962 did not. In a Y-maze spontaneous alternation test of 5.5-month-old $\mathrm{Tg} 2576$ mice, acute GSI treatments also improved short term spatial memory, but 8 days of treatment did not [19]. This lack of effect of subchronic treatment with GSIs on spatial memory was attributed to the accumulation of APP $\beta$-CTF in hippocampal synapses and was consistent with findings in the clinic of worsening of cognition and the ability to perform activities of daily living in $\mathrm{AD}$ patients [18]. In contrast, GSM-2 improved short term spatial memory after both 1 and 8 days of treatment, 

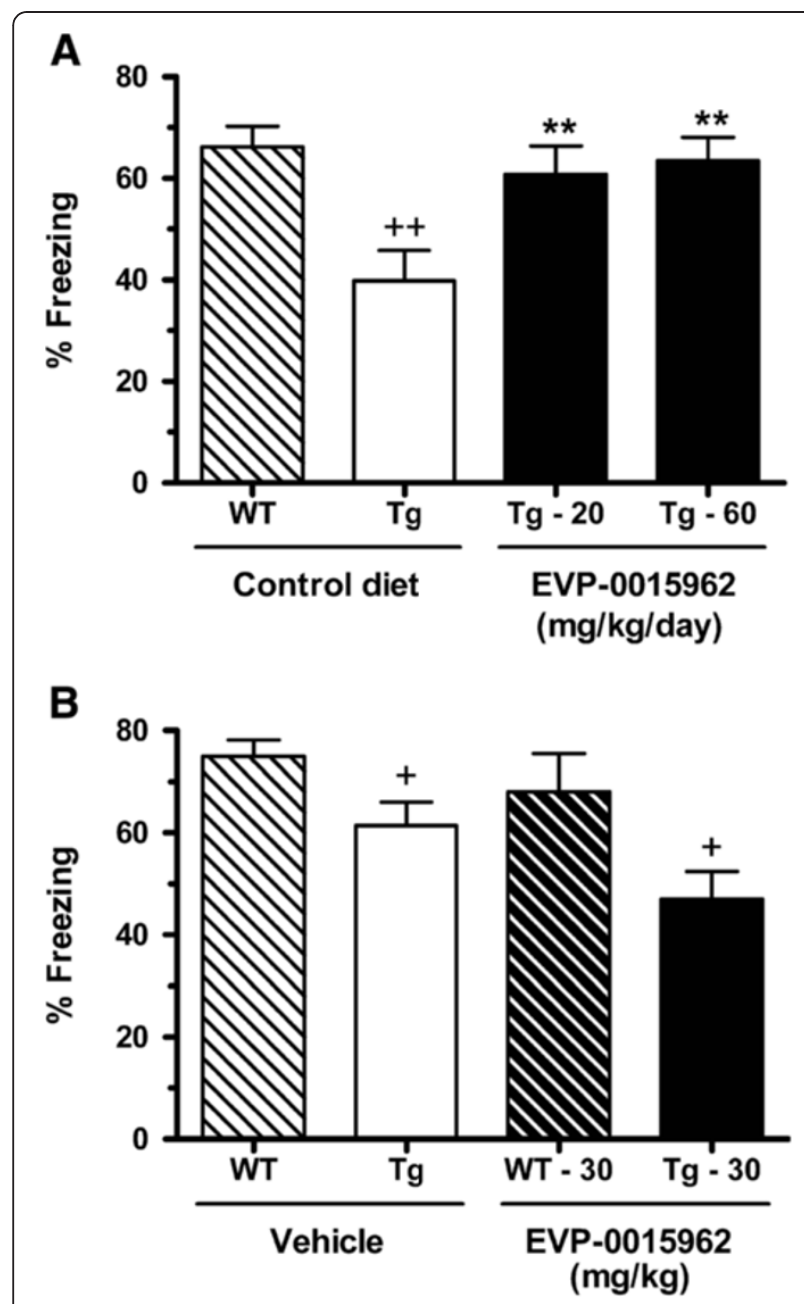

Figure 10 Chronic daily exposure to EVP-0015962 in Tg2576 mice reverses a cognitive decline. A. Percent freezing in the CFC behavioral assay after chronic treatment with EVP-0015962 for 11 weeks in wild type (WT) and Tg2576 (Tg) mice, aged 30-33 weeks. Difference between WT and Tg2576 mice on control diet (i.e., genotype effect): ${ }^{++} p<0.01$. Differences from Tg2576 mice on control diet (i.e., treatment effect): ${ }^{* *} p<0.01 . N=10-15$ mice per group. B. Percent freezing comparing WT and Tg2576 at 30 weeks of age and treated with a single acute dose of $30 \mathrm{mg} / \mathrm{kg}$, p.o. of EVP-0015962 or vehicle. Differences from WT mice receiving the same treatment, either vehicle or $30 \mathrm{mg} / \mathrm{kg}$ of EVP-0015962: ${ }^{+} p<0.05$, indicating a genotype effect but no treatment effect. $\mathrm{N}=10-15$ mice per group. All statistical analyses were performed with 1-way ANOVAs and post-hoc Newman-Keuls tests or t-tests.

suggesting that acute effects of GSMs on cognition can be observed under some experimental conditions [19].

After 50 weeks of chronic daily treatment with EVP0015962 in a food formulation, which began before amyloid plaque deposition (17-26 weeks of age), brain levels of soluble $A \beta_{42}$ were dose dependently reduced. Additionally, increased levels of $\mathrm{A} \beta_{38}$ were observed in the TBS soluble pool of $A \beta$ in the $60 \mathrm{mg} / \mathrm{kg} /$ day group. $\mathrm{A} \beta_{\text {Total }}$ was not changed, similar to what was observed in C57BL/6 mice (data not shown) and Tg2576 mice administered a single dose of EVP-0015962. These findings indicated that EVP-0015962 was modulating $A \beta$ production in the $\mathrm{Tg} 2576$ mice in a similar fashion, whether there were $A \beta$ deposits or not. In addition, $A \beta$ peptides, particularly $A \beta_{42}$ and $A \beta_{\text {Total }}$ (primarily $A \beta_{40}$ ), were decreased in the formic acid extractable pool, albeit to different extents. Since $A \beta$ deposits contain all lengths of $A \beta$ peptides but are primarily composed of $A \beta_{42}$ and $A \beta_{40}$ [4-7], this finding is consistent with a reduction in $\mathrm{A} \beta$ deposition and is supportive of a potential disease modifying effect of EVP-0015962.

As suggested by the reductions in insoluble $A \beta$ peptide levels after chronic treatment with EVP-0015962, A $\beta$ aggregates were also significantly lowered by the high-dose treatment. The degree of reduction in aggregated $A \beta$ (73\%) after treatment with $60 \mathrm{mg} / \mathrm{kg} /$ day of EVP-0015962 was consistent with the reduced levels of $A \beta_{42}$ detected by enzymelinked immunosorbent assay (ELISA) after formic acid extraction of insoluble $A \beta$ (86\%) and of Total $A \beta$ detected by Western blotting (81\%). Interestingly, more disparity among the measures in amount of $A \beta$ reduction was observed for the $20 \mathrm{mg} / \mathrm{kg} /$ day treatment. In the aggregated $A \beta$ assay the reduction was $19 \%$, whereas the reductions by ELISA and Western blotting were larger and similar (about 40-50\%).

Chronic treatment of Tg2576 mice with other GSMs has demonstrated reductions in amyloid deposition [2527]. Similarly, the histological analyses of the chronically treated Tg2576 mice demonstrated reductions in percent area and number of amyloid plaques in the neocortex and hippocampus. Although there was only a small nonsignificant difference between the two doses of EVP0015962, there was a general trend towards a more pronounced effect at the $60 \mathrm{mg} / \mathrm{kg} /$ day dose. Significant reductions were observed in the aggregated $A \beta$ of the plaque cores (visualized with ThioflavinS) and in the more diffuse $A \beta$ surrounding the plaque cores (visualized with the 6E10 antibody) [50-53]. Although both staining procedures produced significant EVP-0015962 treatment effects for percent area and number of plaques, plaque size was only reduced in the ThioflavinS analysis. Since the cores of amyloid plaques are initially seeded by aggregated $A \beta_{42}$ [5], and this is the peptide most reduced by EVP-0015962 treatment, it is likely that the higher number of significant findings with ThioflavinS relates to its preferential staining of the plaque cores, while $6 \mathrm{E} 10$ antibody recognizes $\mathrm{A} \beta$ of various lengths and states of aggregation, which were less altered overall by the treatment. This suggests that EVP0015962 might mediate its effect through a reduction of the amount of $A \beta_{42}$ available for the initial seeding and growth in the size of amyloid plaque core, and maybe less through the subsequent growth of plaques by the addition of $\mathrm{A} \beta$ peptides of other lengths. 
The effect on reactive gliosis was pronounced, and may have been the result of the significant reduction in the amyloid plaque load and/or a direct antiinflammatory activity of EVP-0015962. In enzyme assays for COX-1 and COX-2, the $\mathrm{IC}_{50}$ of EVP-0015962 for COX-1 was $>10 \mu \mathrm{M}(\mathrm{n}=2)$, and the percent inhibition for COX-2 at $30 \mu \mathrm{M}$ was $56 \%(\mathrm{n}=2)$, well above the in vitro $\mathrm{IC}_{50}$ for $\mathrm{A} \beta_{42} \quad(67 \mathrm{nM})$ and the brain exposures of EVP-0015962 after chronic treatment. However, effects of EVP-0015962 on other inflammatory pathways have not been excluded. Nevertheless, since the reactive gliosis in Tg2576 mice on the control diet was localized around the amyloid plaques and $\mathrm{A} \beta$ can activate astrocytes and microglia, as well as induce inflammatory responses [20], it is likely that the EVP-0015962-induced decrease in $A \beta_{42}$ and amyloid plaques at least partially led to the attenuated reactive gliosis. These data suggest that a therapy which reduces $A \beta_{42}$ levels will effectively reduce amyloid plaque formation and the concomitant reactive gliosis.

\section{Conclusions}

We have demonstrated that EVP-0015962 behaves as a GSM. The compound was orally bioavailable, detected in brain, well tolerated after daily treatment in $\operatorname{Tg} 2576$ mice, and decreased $A \beta$ deposition and reactive gliosis. EVP-0015962 was also shown to prevent and/or reverse hippocampal cognitive deficits associated with the decrease in amyloid deposition after chronic treatment. EVP-0015962 is a novel, small molecule GSM with the potential to be a well-tolerated, disease-modifying therapeutic for Alzheimer's disease.

\section{Methods}

\section{EVP-0015962}

EVP-0015962 was synthesized and chirally separated, as described by Shapiro and Chesworth [54]. For in vitro experiments, EVP-0015962 was dissolved in dimethyl sulfoxide (DMSO, Sigma-Aldrich, St. Louis, MO) as a 30 $\mathrm{mM}$ stock solution for dilution into medium. For food formulation studies, EVP-0015962 (20 and $60 \mathrm{mg} / \mathrm{kg} /$ day) was milled into standard mouse chow pellets (AIN93M, Research Diets, Inc., New Brunswick, NJ). Diet doses of EVP-0015962 were calculated based on the desired single daily dose, body weight, and daily food intake. The food formulations of 20 and $60 \mathrm{mg} / \mathrm{kg} /$ day were equivalent to 171 and 514 ppm of EVP-0015962 in the diet, respectively.

\section{COX enzyme assays}

COX-1 and COX-2 enzyme assays were performed by Cerep (Redmond, WA, Catalog \# 0726 and 0727). Briefly, the assays used human recombinant Sf9 cells and arachidonic acid ( $4 \mu \mathrm{M}$ for COX-1 and $2 \mu \mathrm{M}$ for
COX-2) as the substrate. Production of $\mathrm{PGE}_{2}$ was detected by enzyme immunoassay.

\section{Animals}

Animals were maintained on 12/12 h light/dark cycle with food available ad libitum. All procedures were performed with approval from the Institutional Animal Care and Use Committee and were in accordance with the guidelines in the Guide for the Care and Use of Laboratory Animals from the U.S. Department of Health and Human Services.

\section{Cell-based assay for measuring secreted $A \beta$ peptides}

Human neuroglioma H4 cells (ATCC, Manassas, VA) were transfected with a pcDNA3.1 (Invitrogen, Carlsbad, CA) plasmid expressing human wild type $\mathrm{APP}_{751} \mathrm{cDNA}$; and a stable cell line was generated using G418 (Invitrogen) selection [55]. Prior to experimentation, $\mathrm{H} 4-\mathrm{APP}_{751}$ cells were maintained in Dulbecco's modified Eagle's high glucose medium with $10 \%$ fetal bovine serum, $1 \%$ penicillinstreptomycin, $2 \mathrm{mM}$ L-glutamine, and $0.4 \mathrm{mg} / \mathrm{mL}$ G418. All culture reagents were from Invitrogen.

Cells were plated at 15,000 cells/well in Costar 96-well plates (Corning, Corning, NY) and placed at $37^{\circ} \mathrm{C}$ and $5 \% \mathrm{CO}_{2}$. Six hours after plating, cells were washed three times with Pro $293^{\mathrm{TM}}$ chemically defined medium (Lonza, Walkersville, MD) with $1 \%$ penicillin-streptomycin and 2 mM L-glutamine, followed by addition of EVP-0015962 (0.003-10 $\mu \mathrm{M}$, final DMSO concentration of $0.33 \%$ ). Plates were incubated overnight (16-18 h) and supernatant was removed for quantification of $A \beta$ peptides by sandwich ELISA. Cytotoxicity was evaluated using CellTiter $96^{\circledR}$ AQueous One Solution Cell Proliferation Assay (MTS Assay, Promega, Madison, WI) according to the manufacturer's protocol.

\section{Rat primary neocortical cultures}

Primary cultures were established from the neocortex of E17 rat embryos obtained from timed pregnant $\mathrm{CD}$ rats (Charles River Laboratories, Wilmington, MA). Following tissue dissection and trituration, the cultures were suspended in Neurobasal ${ }^{\mathrm{TM}}$ medium (Invitrogen) supplemented with $10 \%$ horse serum (Sigma-Aldrich) and 520 $\mu \mathrm{M}$ L-glutamine [56,57]. Cells were plated at 50,000 cells/ well in Costar 96-well poly-D-lysine-coated plates. Following incubation at $37^{\circ} \mathrm{C}$ and $5 \% \mathrm{CO}_{2}$ for $4-5 \mathrm{~h}$, the plating medium was exchanged with Neurobasal ${ }^{\circledR}$ medium with $2 \% \mathrm{~B}-27^{\circledR}$ supplement (Invitrogen), $520 \mu \mathrm{M}$ of L-glutamine, and $1 \%$ penicillin-streptomycin. Assays were performed at day eight in vitro (DIV8) after replacement of one-half of the medium and addition of EVP-0015962 (0.01-30 $\mu \mathrm{M}$, final DMSO concentration of $0.1 \%$ ). Cultures were incubated with compound for $24 \mathrm{~h}$ for analysis of $\mathrm{A} \beta$ peptides by sandwich ELISA and cytotoxicity by MTS assay. 


\section{$A \beta$ measurements}

$A \beta$ peptide levels were quantified by sandwich ELISA. Plates were coated overnight at $4^{\circ} \mathrm{C}$ with either human anti-A $\beta_{\text {Total }}$ (amino acids [aa] 27-37) or rodent anti$A \beta_{1-x}$ (aa 1-8) rabbit polyclonal antibodies. For detection of $A \beta_{38}$ and $A \beta_{42}$, plates were coated with antibodies specific for the carboxyl-terminal neoepitope of each peptide. Antibodies were from Dr. Pankaj Mehta (Institute for Basic Research in Developmental Disabilities, Staten Island, NY) [58].

Freshly collected samples of cultured cell supernatant or synthetic peptides (American Peptide Co., Sunnyvale, CA or California Peptide Research, Inc., Napa, CA) for standard curves were diluted with media, and loaded into anti-A $\beta$ antibody-coated plates and incubated at $4^{\circ}$ $\mathrm{C}$ for about $24 \mathrm{~h}$. A $\beta$ peptides were detected with the 4G8 antibody (A $\beta$, aa 17-24) conjugated to horseradish peroxidase (Covance, Inc., Princeton, NJ), and SureBlue 3,3,5,5'-tetramethylbenzidine (TMB) peroxidase substrate (KPL, Inc., Gaithersburg, MA). Following addition of TMB stop solution (KPL, Inc.), plates were read for absorbance at $450 \mathrm{~nm}$ (SpectraMax M5e Microplate Reader, Molecular Devices, Inc., Sunnyvale, CA). EVP0015962-treated samples were normalized to samples treated with DMSO alone (no inhibition) and to samples treated with DAPT (5 $\mu \mathrm{M}$, Sigma-Aldrich). $\mathrm{IC}_{50}$ and $\mathrm{EC}_{50}$ values were calculated from values reported as percent of DMSO controls using nonlinear regression, based on a sigmoidal dose-response (variable slope) model. All data were analyzed in Prism 4 (GraphPad Software, Inc., San Diego, CA).

\section{MALDI-TOF mass spectrometry}

Immunoprecipitation of carboxyl-terminally truncated $\mathrm{A} \beta$ peptides from $4 \mathrm{~mL}$ of $\mathrm{H} 4$ cell media was conducted using $A \beta$-specific antibodies coupled to magnetic beads as described elsewhere [59]. The anti-A $\beta$ antibodies 6E10 and 4G8 (Covance, Inc.) were used. After elution of the immune-purified $A \beta$ peptides, the detections were performed on an UltraFlextreme MALDI-TOF/TOF instrument (Bruker Daltonics, Bremen, Germany).

\section{AICD production}

The effects of increasing concentrations of EVP0015962 on cleavage products of APP were tested in a cell-free system. DAPT was used as a reference positive control for the assay. For each assay condition, a $5-\mu \mathrm{L}$ microsomal fraction, containing $1 \%$ CHAPSO (3-[(3-cholamidopropyl)dimethylammonio]-2-hydroxy1-propanesulfonate) from murine embryonic fibroblasts (MEF) lacking the Aph-1A, Aph-1B, and Aph-1C genes [60] (triple knock out) and rescued with Aph-1 $A_{L}$, was prepared in a reaction mixture of $5 \mu \mathrm{L}$ substrate (recombinant APP $\beta$-CTF 3-Flag-tagged) at $0.8 \mu \mathrm{M}$,
0.0125\% phosphatidylethanolamine, $0.1 \%$, phosphatidylcholine, $0.05 \%$ sphingomyelin, and $8.9 \mu \mathrm{L}$ PIPES (piperazine-N,N/-bis[-ethanesulfonic acid]) buffer. EVP$0015962(0.001-100 \mu \mathrm{M})$ or DAPT $(10 \mu \mathrm{M})$ in $0.5 \mu \mathrm{L}$ of DMSO was added to the reaction mixture and incubated at $37^{\circ} \mathrm{C}$ for $3 \mathrm{~h}$. For detection of AICD, one-half of the reaction mixture was purified by a methanolchloroform extraction in order to remove lipids and hydrophobic proteins (e.g., APP $\beta$-CTF). This purified fraction was further analyzed by SDS-PAGE and Western blotting. AICD was detected with an ANTI-FLAG ${ }^{\circledR}$ antibody (Sigma-Aldrich). The other half of the reaction mixture was used to analyze the levels of $A \beta_{1-40}$ and $\mathrm{A} \beta_{1-42}$ by AlphaLisa (Perkin Elmer, Waltham, MA).

\section{APP CTF assays}

To evaluate the accumulation of APP $\alpha$ - and $\beta$-CTFs, $\mathrm{H} 4-\mathrm{APP}_{751}$ cells were treated for $16 \mathrm{~h}$ with EVP0015962 or the GSI LY-411,575 (Alchem Laboratories Corp., Alachua, FL) at 0.001-10 $\mu \mathrm{M}$. Cells were lysed in situ and the resulting lysate cleared of nuclei by centrifugation, as described elsewhere [61]. Samples were fractionated by SDS-PAGE on a $12 \%$ NuPage gel (Invitrogen), transferred to a nitrocellulose membrane, and immunoblotted with an anti-APP-CTF antibody (Sigma-Aldrich). Following incubation with an IRDye secondary antibody (Li-Cor Biosciences, Lincoln, NE), detection was performed using an Odyssey scanner (LiCor Biosciences).

For determination of APP $\alpha$ - and $\beta$-CTFs in Tg2576 mouse brain, hemisphere samples were thawed in icecold homogenization buffer $(150 \mathrm{mg}$ of tissue/mL, 50 $\mathrm{mM}$ Tris and $150 \mathrm{mM} \mathrm{NaCl}, \mathrm{pH}$ 7.4) with protease inhibitor cocktail (Mini Complete ${ }^{\mathrm{TM}}$, Roche Applied Science, Penzberg, Germany). Homogenized samples were spun at $435,000 \mathrm{~g}$ for $50 \mathrm{~min}$ at $4^{\circ} \mathrm{C}$. The supernatant was discarded and the pellet resuspended in the same volume of homogenization buffer containing $0.5 \%$ Triton ${ }^{\circledR}$-X 100, 1\% deoxycholate, and 3\% SDS. The pellets were triturated with a pipette until resuspended and incubated on a rotator for $1 \mathrm{~h}$ at $4^{\circ} \mathrm{C}$. The samples were then centrifuged at $435,000 \mathrm{~g}$ for $50 \mathrm{~min}$ at $4^{\circ} \mathrm{C}$ and the detergent-soluble supernatant was collected. Protein concentration for membrane (detergent soluble) fraction was determined using the BCA method (Pierce, Rockford, IL). Thirty micrograms of total protein were separated on a Tricine $10-20 \%$ gel (Invitrogen) and transferred to a nitrocellulose membrane. Blots were probed with an anti-APP-CTF antibody (Sigma-Aldrich) or anti-A $\beta$ antibody (clone 6E10) followed by incubation with IRDye secondary antibodies (Li-Cor Biosciences). Detection was performed using an Odyssey scanner (LiCor Biosciences) and blots quantified using ImageJ software (available at http://rsbweb.nih.gov/ij). 


\section{NICD production}

HEK293 cells (700,000 cells per assay condition) were transiently transfected with a Notch $\Delta \mathrm{E}$, myc-tagged construct to produce a truncated Notch1 substrate, which is constitutively cleaved by $\gamma$-secretase (S3 cleavage) [62]. Control transfections were performed with an empty vector. Twenty-four hours after transfection, the cells were treated with EVP-0015962 $(0.001-30 \mu \mathrm{M})$ or DMSO (control) for $20 \mathrm{~h}$. Lactacystin $(10 \mu \mathrm{M}$, SigmaAldrich) was used to prevent degradation of NICD. Cell lysates were analyzed by SDS-PAGE and Western blotting using a c-myc monoclonal antibody (9E10, Santa Cruz Biotechnology, Santa Cruz, CA) and a cleaved Notch1 antibody (Cell Signaling Technology, Beverly, MA). The amounts of NICD and total Notch were quantified and NICD was expressed as a percentage of total Notch. The DMSO control condition was set at $100 \%$. Cell viability was determined using the CellTiter-Blue ${ }^{\circledR}$ Cell Viability Assay (Promega).

\section{EphA4 CTF assay}

Rat primary neocortical cultures (DIV14) were treated with $0.1-10 \mu \mathrm{M}$ of EVP-0015962 or LY-411,575 for $24 \mathrm{~h}$. Cells were lysed with RIPA buffer $(50 \mathrm{mM}$ Tris- $\mathrm{HCl}$, $\mathrm{pH}$ 7.4, $150 \mathrm{mM} \mathrm{NaCl}, 0.25 \%$ deoxycholic acid, 1\% NP40, and 1 mM EDTA) (Upstate, Temecula, CA) containing protease inhibitors and samples centrifuged for 8 $\min$ at $16,200 \mathrm{~g}$ to remove cell debris. Protein concentration of the lysate was determined by the BCA method, and $30 \mu \mathrm{g}$ of total protein were loaded on a $10 \%$ Bis-Tris gel (Invitrogen). EphA4 CTF was visualized using an anti-EphA4-CTF antibody (Abnova, Walnut, CA) and an IRDye800CW ${ }^{\circledR}$ secondary antibody (Rockland Immunochemicals, Inc., Gilbertsville, PA). Detection was performed using an Odyssey scanner (LiCor Biosciences) and blots quantified using ImageJ software (available at http://rsbweb.nih.gov/ij).

\section{Acute treatment study in Tg2576 mice}

EVP-0015962 was prepared in a vehicle of 10\% DMSO, $15 \%$ Solutol $^{\circledR}$ HS 15 (BASF, Ludwigshafen, Germany), $10 \%$ ethyl alcohol, and 65\% water. The 10 and $30 \mathrm{mg} / \mathrm{kg}$ doses were a solution and a suspension, respectively. Male Tg2576 mice (B6;SJL-Tg(APPSWE)2576Kha, model 1349, Taconic, Hudson, NY) were used at 21 weeks of age [36]. Mice (24-35 g body weight) were administered 10 or $30 \mathrm{mg} / \mathrm{kg}$, p.o. of EVP-0015962 without prior fasting, and euthanized by $\mathrm{CO}_{2}$ asphyxiation $4 \mathrm{~h}$ post-dosing. After extraction of the brain, olfactory bulbs and hindbrain were removed and the cerebral hemispheres were cut into 4 pieces. Cerebellum was removed for bioanalysis of EVP-0015962 concentrations. All tissue samples were weighed, frozen in liquid nitrogen, and stored at $-80^{\circ} \mathrm{C}$ until analysis.

\section{Chronic treatment studies in Tg2576 mice}

Male C57BL/6 mice (Charles River Laboratories, 10-12 weeks of age, 24-32 g body weight) were group housed (3-5 per cage) and used in pilot studies to establish the concentrations of EVP-0015962 for the food formulations for the chronic treatment studies. Mice were placed on the food formulations for 3 or 7 days and were euthanized, as described above, approximately $1 \mathrm{~h}$ after the onset of the light cycle.

Male Tg2576 and WT mice were both derived from crosses of male Tg2576 mice and female B6SJLF1 mice (Taconic) and were singly housed upon arrival. At 16-23 weeks of age, mice were placed on the control diet (AIN$93 \mathrm{M}$ ), and one week later, were switched to the experimental diets (EVP-0015962 at 20 or $60 \mathrm{mg} / \mathrm{kg} /$ day) or maintained on the control diet. Tg2576 mice were maintained on the food formulations containing EVP-0015962 for 11,28 , or 50 weeks, and were sacrificed at 2-4 h after the onset of the light cycle. Some animals were euthanized as described above. For histological studies, a subset of mice were euthanized by $\mathrm{CO}_{2}$ asphyxiation and transcardially perfused with cold $0.9 \% \mathrm{NaCl}$. The right hemispheres were immersion fixed in fresh $4 \%$ paraformaldehyde in $0.1 \mathrm{M}$ phosphate buffer, $\mathrm{pH} 7.4$ for 1 $\mathrm{h}$, transferred to a $15 \%$ sucrose cryoprotectant for $24 \mathrm{~h}$ at room temperature, and on the next day, frozen in isopentane chilled by dry ice for $1 \mathrm{~min}$. The left cerebral hemisphere was cut into 2 pieces, weighed, and frozen.

\section{Measurement of EVP-0015962 in brain}

Cerebellums were homogenized in a Mini-BeadBeater (Biospec Products, Inc., Bartlesville, OK). Brain samples and calibration standards in brain homogenate were prepared for liquid chromatography-tandem mass spectroscopy (LC-MS/MS) by precipitating proteins with acetonitrile and vacuum filtration in the presence of an internal standard (EVP-0015962-D 6 ). EVP-0015962 was resolved by HPLC (Shimadzu, Kyoto, Japan) using a reverse-phase Xterra ${ }^{\circledR}$ C18 column $(100 \times 2.1 \mathrm{~mm}$ i.d. $)$ (Waters Corp., Milford, MA). Following separation, the column effluent was introduced into a hybrid triple quadrupole/linear ion trap mass spectrometer (API 3200 Q-Trap, Applied Biosystems, Foster City, CA), optimized for detection of EVP-0015962 and using multiple reaction monitoring with mass transition of $479.300>296.700$. Concentration of EVP-0015962 was measured as nanograms per gram of brain and expressed as micromolar.

\section{Sequential $A \beta$ extraction from Tg2576 mouse brain}

In order to examine both soluble and insoluble pools of $\mathrm{A} \beta$, sequential extraction of $\mathrm{Tg} 2576$ mouse brain samples was performed to produce 4 pools of $A \beta$, essentially as described elsewhere [37]. Briefly, brains were homogenized in $25 \mathrm{mM}$ TBS, pH 7.4 with protease inhibitors (Mini 
Complete $^{\mathrm{TM}}$ ) to release the soluble $\mathrm{A} \beta$ into the resulting supernatants after high speed ultracentrifugation. The above procedure was then repeated with the pellets from the previous extraction step, using $1 \%$ Triton ${ }^{\circledR}$-X 100 in TBS with protease inhibitors, $2 \%$ SDS with protease inhibitors, and $68.75 \%$ formic acid. The extracted $A \beta$ from each step was subjected to ELISA for human $A \beta_{42}, A \beta_{38}$, and $\mathrm{A} \beta_{\text {Total }}$, as described above.

\section{Detection of aggregated $A \beta$ in Tg2576 mouse brain}

The A4 assay (Amorfix Life Sciences, Toronto, Canada) was employed to quantify levels of aggregated $A \beta$ in $\mathrm{Tg} 2576$ mouse brains. Brain samples were homogenized in 10 volumes of $2 \%$ NP-40 in phosphate buffered saline (PBS, pH 7.4) containing $1 \mathrm{mM}$ phenylmethanesulfonylfluoride (PMSF) and protease inhibitors (Mini Complete $\left.^{\mathrm{TM}}\right)$. The homogenates were further diluted in PBS with $0.05 \%$ Tween ${ }^{\circledR} 20$ and $1 \%$ bovine serum albumin to a final concentration that would provide a signal within the linear range of the immunoassay. A sample enrichment protocol, proprietary to Amorfix Life Sciences, was used to specifically isolate oligomeric and aggregated $A \beta$ rather than monomeric $A \beta$. Following enrichment, samples were eluted and disaggregated to allow detection of now monomeric $A \beta$ [63]. $A \beta$ was detected by immunoassay following incubation at $37^{\circ} \mathrm{C}$ with europium-fluorescent beads coupled to the mouse monoclonal 4G10 antibody (N-terminal A $\beta$, aa 117) and magnetic beads coupled to the antibodies $1 \mathrm{~F} 8$ (C-terminal $\mathrm{A} \beta$, aa 3-40) and $2 \mathrm{H} 12$ (C-terminal $\mathrm{A} \beta$, aa 3-42). 4G10, 1F8, 2H12 were produced by Amorfix Life Sciences. Following incubations the samples were placed on a magnet to isolate the immune complex. The intensity of the europium fluorescent signal was measured using time resolved fluorescence on each sample in triplicate and was taken as being directly proportional to the concentration of aggregated $A \beta$ in the sample. The limit of detection using this assay was $50 \mathrm{fg}$ per well. The fluorescent signal for each mouse relative to the background noise for the assay was then expressed as percent of the control diet group.

\section{Histology}

The right hemispheres were sectioned at $20 \mu \mathrm{m}$ in the sagittal plane. From 12 levels, 7 sections were retained and processed. $A \beta$ plaque load was quantified in sections doubly stained by immunohistochemistry with $6 \mathrm{E} 10$ antibody (N-terminal human $\mathrm{A} \beta$, aa 1-16) and by ThioflavinS. Astrocytes were immunostained using a primary rabbit polyclonal antibody against GFAP (Dako, Glostrup, Denmark) and a fluorescently labelled secondary Cy2 antibody (Jackson ImmunoResearch Laboratories, West Grove, PA). Activated microglia were immunostained using a rat anti-murine CD11b primary antibody (AbD Serotec,
Kidlington, UK) and a fluorescently labelled secondary Cy3 antibody (Jackson ImmunoResearch Laboratories). Astrocytes and microglia were labelled in a double incubation and sections were counterstained with DAPI to visualize cell nuclei.

Hippocampus and neocortex were measured separately, and the percent area of immunoreactivity or ThioflavinS staining per brain region was evaluated using automated image analysis software (Image Pro Plus, v. 6.2, Media Cybernetics, Bethesda, MD). Numbers and sizes of $A \beta$ deposits were also counted automatically. Measurements from 5 sections per mouse were averaged and the individual mouse average was used to calculate the group means.

\section{Contextual fear conditioning assay}

A 2-day CFC paradigm was used, and the effects of acute and chronic dosing of EVP-0015962 were assessed. For the acute study, EVP-0015962 was prepared as a suspension in a vehicle of 4.5\% DMSO, 15\% Solutol ${ }^{\circledR}$ HS $15,10 \%$ ethyl alcohol, and $70.5 \%$ water. On day 1 , acutely dosed mice were administered $30 \mathrm{mg} / \mathrm{kg}$, p.o. of EVP0015962, $3 \mathrm{~h}$ prior to training. Animals in the food formulation groups were maintained on the compound formulated diets. The training session on day 1 consisted of the following sequence: $3 \mathrm{~min}$ acclimation to the test chamber (Kinder Scientific, Poway, CA), 2 s 1.5 mA foot shock, 2 min wait period, another $2 \mathrm{~s} 1.5 \mathrm{~mA}$ foot shock, followed by a final 1 min wait period. On day 2, testing consisted of returning the animals to the chamber for $5 \mathrm{~min}$ and the total time spent freezing was measured by an automated software system (Kinder Scientific). Freezing was defined as the absence of movement (i.e., zero beam breaks) and was measured every second for the 5-min trial duration (maximum freezing score of 300). Percentage of time spent freezing for each mouse was calculated using the formula: (number of seconds with zero beam breaks/300) X 100.

\section{Statistics}

In vivo data were expressed and graphed as mean \pm SEM. Group differences for A $\beta$ peptide levels, APP processing fragments, histological measures, and behavioral measures were assessed by one-way analyses of variance (ANOVA) followed by Newman-Keuls post-hoc testing or by Student's t-test. Differences in aggregated $A \beta$ were assessed by non-parametric Kruskal-Wallis ANOVA followed by Dunn's test since the groups did not have equal variances. The level of significance was set at $\mathrm{p}<0.05$ in all tests.

\section{Competing interests}

EnVivo Pharmaceuticals, Inc. has a financial interest in EVP-0015962 and funded this research. KR, KMF, LH, ZT, FA, WL, SH, MJM, DS, ZY, HH, SN, MW, $D C, J-F B, E F, M A, D F, L L, H P, R C$, and GK received compensation and stock and/or options as current or former employees of EnVivo Pharmaceuticals, Inc. GS, BD, W, HZ, and EP received compensation as consultants of EnVivo Pharmaceuticals, Inc. LS was an employee of Amorfix, Inc. and received compensation from EnVivo Pharmaceuticals, Inc. BHP and DH are employees 
of QPS Austria GmbH and received compensation from EnVivo Pharmaceuticals, Inc.

\section{Authors' contributions}

KR contributed to the experimental design and interpretation of all studies and wrote the manuscript. RC and GS designed EVP-0015962 and oversaw its synthesis. KMF, LH, ZT, FA, WL, SH, MM, DS, ZY, HH, DC, J-FB, EF, BDS, W, $L S, H Z, E P, B H P, D H, L L$, and HP contributed to the design, execution and interpretation of the studies. SN and MW performed the bioanalytical analyses. DF performed statistical analyses and contributed to the preparation of the manuscript. MA, RC, and GK contributed to the experimental design and interpretation of studies. All authors have read and approved the final manuscript.

\section{Acknowledgements}

The human wild type APP 751 construct was a generous gift of Dr. Rudy Tanzi.

\section{Author details}

${ }^{1}$ EnVivo Pharmaceuticals, Inc, 500 Arsenal Street, Watertown, MA 02472, USA. ${ }^{2}$ VIB Center for The Biology of Disease, Herestraat 49, Box 602, Leuven 3000, Belgium. ${ }^{3}$ KULeuven and University Hospitals, Center for Human Genetics and LIND, Leuven 3000, Belgium. ${ }^{4}$ Amorfix Life Sciences, 3403 American Drive, Mississauga, Ontario L4V 1T4, Canada. ${ }^{5}$ Clinical Neurochemistry Laboratory, Department of Psychiatry and Neurochemistry, Institute of Neuroscience and Physiology, The Sahlgrenska Academy, University of Gothenburg, Mölndal S-43180, Sweden. ${ }^{6} U C L$ Institute of Neurology, Queen Square, London WC1N 3BG, UK. ${ }^{7}$ QPS Austria GmbH, Parkring 12, Grambach A-8074, Austria. ${ }^{8}$ Present address: CoMentis Research Facility, 865 Research Parkway, Suite 400, Oklahoma City, OK 73104, USA. ${ }^{9}$ Present address: Department of Neuroscience, Center for Translational Research in Neurodegenerative Disease, University of Florida College of Medicine, 1275 Center Drive, BMS J-484, Gainesville FL 32610, USA. ${ }^{10}$ Present address: Eisai, Inc., 4 Corporate Dr, Andover, MA 01810, USA. " $P$ Present address: Neuroscience Department, The Ohio State University, Columbus, $\mathrm{OH} 43210$, USA. ${ }^{12}$ Present address: Galenea, 300 Technology Square \# 2, Cambridge, MA 02139, USA. ${ }^{13}$ Present address: University of Maryland Baltimore, 650 West Baltimore St., Room 7211, Baltimore, MD 21201, USA. ${ }^{14}$ Present address: Biopharmaceuticals, Apotex, Inc, 150 Signet Drive, Toronto, Ontario M9L 1T9, Canada. ${ }^{15}$ Present address: Neuroscience Biology, Bristol-Myers Squibb, Research and Development, 5 Research Parkway, Wallingford, CT 06492, USA. ${ }^{16}$ Present address: Pharmore, Inc, 5507 NW 80th Ave, Gainesville, FL 32653, USA. ${ }^{17}$ Present address: Epizyme, Inc, 325 Vassar Street, Suite 2B, Cambridge, MA 02139, USA.

Received: 8 July 2012 Accepted: 14 December 2012

Published: 18 December 2012

\section{References}

1. Alzheimer A: Über eine eigenartige erkrankung der hirnrinde. Allg Zschr Psychiatr 1907, 64:146-148.

2. McKhann GM, Knopman DS, Chertkow H, Hyman BT, Jack CR Jr, Kawas CH, Klunk WE, Koroshetz WJ, Manly JJ, Mayeux R, Mohs RC, Morris JC, Rossor MN, Scheltens P, Carrillo MC, Thies B, Weintraub S, Phelps CH: The diagnosis of dementia due to Alzheimer's disease: recommendations from the national institute on aging-Alzheimer's association workgroups on diagnositc guidelines for Alzheimer's disease. Alzheimers Dement 2011, 7:263-269.

3. Braak H, Braak E: Neuropathological stageing of Alzheimer-related changes. Acta Neuropathol 1991, 82:239-259.

4. Masters $C L$, Simms G, Weinman NA, Multhaup G, McDonald BL, Beyreuther $\mathrm{K}$ : Amyloid plaque core protein in Alzheimer disease and Down syndrome. Proc Natl Acad Sci USA 1985, 82:4245-4249.

5. Iwatsubo T, Odaka A, Suzuki N, Mizusawa H, Nukina N, Ihara Y: Visualization of $A \beta 42(43)$ and $A \beta 40$ in senile plaques with end-specific $A \beta$ monoclonals: evidence that an initially deposited species is $A \beta 42(43)$. Neuron 1994, 13:45-53.

6. Saido TC, Yamao-Harigaya W, Iwatsubo T, Kawashima S: Amino- and carboxyl-terminal heterogeneity of $\beta$-amyloid peptides deposited in human brain. Neurosci Lett 1996, 215:173-176.

7. Murphy MP, LeVine H III: Alzheimer's disease and the $\beta$-amyloid peptide. J Alzheimers Dis 2010, 19:311-323.
8. Selkoe DJ: Alzheimer's disease: genes, proteins, and therapy. Physiol Rev 2001, 81:741-766.

9. Selkoe DJ, Wolfe MS: Presenilin: running with scissors in the membrane. Cell 2007, 131:215-221.

10. Thinakaran G, Koo EH: Amyloid precursor protein trafficking, processing, and function. J Biol Chem 2008, 283:29615-29619.

11. Beher D, Wrigley JD, Owens AP, Shearman MS: Generation of C-terminally truncated amyloid- $\beta$ peptides is dependent on $\gamma$-secretase activity. J Neurochem 2002, 82:563-575.

12. Karran E, Mercken M, De Strooper B: The amyloid cascade hypothesis for Alzheimer's disease: an appraisal for the development of therapeutics. Nat Rev Drug Discov 2011, 10:698-712.

13. Lleó A, Saura CA: Y-secretase substrates and their implications for drug development in Alzheimer's disease. Curr Top Med Chem 2011, 11:1513-1527.

14. Pardossi-Piquard R, Checler F: The physiology of the $\beta$-amyloid precursor protein intracellular domain AICD. J Neurochem 2012, 120 (Suppl 1):109-124.

15. De Strooper B, Annaert W, Cupers P, Saftig P, Craessaerts K, Mumm JS, Schroeter EH, Schrijvers V, Wolfe MS, Ray WJ, Goate A, Kopan R: A presenilin-1-dependent $\gamma$-secretase-like protease mediates release of notch intracellular domain. Nature 1999, 398:518-522.

16. Wong GT, Manfra D, Poulet FM, Zhang Q, Josien H, Bara T, Engstrom L, Pinzon-Ortiz M, Fine JS, Lee H-JJ, Zhang L, Higgins GA, Parker EM: Chronic treatment with the $\gamma$-secretase inhibitor LY-411,575 inhibits $\beta$-amyloid peptide production and alters lymphopoiesis and intestinal cell differentiation. J Biol Chem 2004, 279:12876-12882.

17. Fleisher AS, Raman R, Siemers ER, Becerra L, Clark CM, Dean RA, Farlow MR, Galvin JE, Peskind ER, Quinn JF, Sherzai A, Sowell BB, Aisen PS, Thal LJ: Phase 2 safety trial targeting amyloid $\beta$ production with a $\gamma$-secretase inhibitor in Alzheimer disease. Arch Neurol 2008, 65:1031-1038.

18. Imbimbo BP, Panza F, Frisardi V, Solfrizzi V, D'Onofrio G, Logroscino G, Seripa $D$, Pilotto A: Therapeutic intervention for Alzheimer's disease with $\gamma$ secretase inhibitors: still a viable option? Expert Opin Investig Drugs 2011, 20:325-341.

19. Mitani Y, Yarimizu J, Saita K, Uchino H, Akashiba H, Shitaka Y, Ni K, Matsuoka $\mathrm{N}$ : Differential effects between $\gamma$-secretase inhibitors and modulators on cognitive function in amyloid precursor protein-transgenic and nontransgenic mice. J Neurosci 2012, 32:2037-2050.

20. Akiyama H, Barger S, Barnum S, Bradt B, Bauer J, Cole GM, Cooper NR, Eikelenboom P, Emmerling M, Fiebich BL, Finch CE, Frautschy S, Griffin WST, Hampel H, Hull M, Landreth G, Lue L-F, Mrak R, Mackenzie IR, McGeer PL, O'Banion MK, Pachter J, Pasinetti G, Plata-Salaman C, Rogers J, Rydel R, Shen Y, Streit W, Strohmeyer R, Tooyoma I, et al: Inflammation and Alzheimer's disease. Neurobiol Aging 2000, 21:383-421.

21. Ferretti MT, Cuello AC: Does a pro-inflammatory process precede Alzheimer's disease and mild cognitive impairment? Curr Alzheimer Res 2011, 8:164-174.

22. Weggen S, Eriksen JL, Das P, Sagi SA, Wang R, Pietrzik CU, Findlay KA, Smith TE, Murphy MP, Bulter T, Kang DE, Marquez-Sterling N, Golde TE, Koo EH: A subset of NSAIDs lower amyloidogenic A 442 independently of cyclooxygenase activity. Nature 2001, 414:212-216.

23. Weggen S, Eriksen JL, Sagi SA, Pietrzik CU, Ozols V, Fauq A, Golde TE, Koo EH: Evidence that nonsteroidal anti-inflammatory drugs decrease amyloid $\beta 42$ production by direct modulation of $\gamma$-secretase activity. J Biol Chem 2003, 278:31831-31837.

24. Sagi SA, Weggen S, Eriksen J, Golde TE, Koo EH: The non-cyclooxygenase targets of non-steroidal anti-inflammatory drugs, lipoxygenases, peroxisome proliferator-activated receptor, inhibitor of $\mathrm{KB}$ kinase, and NFKB, do not reduce amyloid $\beta 42$ production. J Biol Chem 2003, 278:31825-31830.

25. Imbimbo BP, Del Giudice E, Colavito D, D'Arrigo A, Dalle Carbonare M, Villetti G, Facchinetti F, Volta R, Pietrini V, Baroc MF, Serneels L, De Strooper B, Leon A: 1-(3/,4/-Dichloro-2-fluoro[1,1/-biphenyl]4-yl)-cyclopropanecarboxylic acid (CHF5074), a novel $\gamma$-secretase modulator, reduces brain $\beta$-amyloid pathology in a transgenic mouse model of Alzheimer's disease without causing peripheral toxicity. J Pharmacol Exp Ther 2007, 323:822-830.

26. Kounnas MZ, Danks AM, Cheng S, Tyree C, Ackerman E, Zhang X, Ahn K, Nguyen P, Comer D, Mao L, Yu C, Pleynet D, Digregorio PJ, Velicelebi G, Stauderman KA, Comer WT, Mobley WC, Li Y-M, Sisodia SS, Tanzi RE, Wagner SL: Modulation of $\gamma^{-}$ secretase reduces $\beta$-amyloid deposition in a transgenic mouse model of Alzheimer's disease. Neuron 2010, 67:769-780. 
27. Van Broeck B, Chen JM, Tréton G, Desmidt M, Hopf C, Ramsden N, Karran E, Mercken M, Rowley A: Chronic treatment with a novel $\gamma$-secretase modulator, JNJ-40418677, inhibits amyloid plaque formation in a mouse model of Alzheimer's disease. Br J Pharmacol 2011, 163:375-389.

28. Hawkins J, Harrsion DC, Ahmed S, Davis RP, Chapman T, Marshall I, Smith B, Mead TL, Medhurst A, Giblin GMP, Hall A, Gonzalez Ml, Richardson J, Hussain I: Dynamics of $A \beta 42$ reduction in plasma, CSF and brain of rats treated with the $\gamma$-secretase modulator, GSM-10h. Neurodegener Dis 2011, 8:455-464.

29. Borgegard T, Juréus A, Olsson F, Rosqvist S, Sabirsh A, Rotticci D, Paulsen $K$, Klintenberg R, Yan H, Waldman M, Stromberg K, Nord J, Johansson J, Regner A, Parpal S, Malinowsky D, Radesater A-C, Li T, Singh R, Eriksson H, Lundkvist J: First and second generation gamma-secretase modulators (GSMs) modulate abeta production through different mechanisms. J Biol Chem 2012, 287:11810-11819.

30. Basi GS, Hemphill S, Brigham EF, Liao A, Aubele DL, Baker J, Barbour R, Bova M, Chen X-H, Dappen MS, Eichenbaum T, Goldbach E, Hawkinson J, LawlerHerbold R, Hu K, Hui T, Jagodzinski JJ, Keim PS, Kholodenko D, Latimer LH, Lee M, Marugg J, Mattson MN, McCauley S, Miller JL, Motter R, Mutter L, Neitzel ML, Ni H, Nguyen L, et al: Amyloid precursor protein selective gamma-secretase inhibitors for treatment of Alzheimer's disease. Alzheimers Res Ther 2010, 2:36

31. Saxena MT, Schroeter EH, Mumm JS, Kopan R: Murine notch homologs (N1-4) undergo presenilin-dependent proteolysis. J Biol Chem 2001, 276:40268-40273.

32. Sinha S, Lieberburg I: Cellular mechanisms of $\beta$-amyloid production and secretion. Proc Natl Acad Sci USA 1999, 96:11049-11053.

33. DeStrooper B, Saftig P, Craessaerts K, Vanderstichele H, Guhde G, Annaert W, Von Figura K, Van Leuven F: Deficiency of presenilin-1 inhibits the normal cleavage of amyloid precursor protein. Nature 1998, 391:387-340.

34. Naruse S, Thinakaran G, Luo JJ, Kusiak JW, Tomita T, Iwatsubo T, Qian X, Ginty DD, Price DL, Borchelt DR, Wong PC, Sisodia SS: Effects of PS1 deficiency on membrane protein trafficking in neurons. Neuron 1998, 5:1213-1221.

35. Inoue E, Deguchi-Tawarada M, Togawa A, Matsui C, Arita K, Katahira-Tayama S, Sato T, Yamauchi E, Oda Y, Takai Y: Synaptic activity prompts $Y$ secretase-mediated cleavage of EphA4 and dendritic spine formation. J Cell Biol 2009, 185:551-564.

36. Hsiao K, Chapman P, Nilsen S, Eckman C, Harigaya Y, Younkin S, Yang F, Cole $\mathrm{G}$ : Correlative memory deficits, $\mathrm{A} \beta$ elevation, and amyloid plaques in transgenic mice. Science 1996, 274:99-102.

37. Kawarabayashi T, Younkin LH, Saido TC, Shoji M, Ashe KH, Younkin SG: Agedependent changes in brain, CSF, and plasma amyloid $\beta$ protein in the Tg2576 transgenic mouse model of Alzheimer's disease. J Neurosci 2001, 21:372-381.

38. Anagnostaras SG, Gale GD, Fanselow MS: Hippocampus and contextual fear conditioning: recent controversies and advances. Hippocampus 2001, 11:8-17.

39. Comery TA, Martone RL, Aschmies S, Atchison KP, Diamantidis G, Gong X, Zhou $\mathrm{H}$, Kreft AF, Pangalos MN, Sonnenberg-Reines J, Jacobsen JS, Marquis KL: Acute Y-secretase inhibition improves contextual fear conditioning in the $\operatorname{Tg} 2576$ mouse model of Alzheimer's disease. J Neurosci 2005, 25:8898-8902.

40. Imbimbo BP, Giardino L, Giuliani A, Gusciglio M, Pietrini V, Del Giudice E, D'Arrigo A, Leon A, Villetti G, Calzà L: CHF5074, A novel $\gamma$-secretase modulator, restores hippocampal neurogenesis potential and reverses contextual memory deficit in a transgenic mouse model of Alzheimer's disease. J Alzheimers Dis 2010, 20:159-173.

41. McGeer PL, McGeer EG: NSAIDs and Alzheimer disease: epidemiological, animal model and clinical studies. Neurobiol Aging 2007, 28:639-647.

42. Lim GP, Yang F, Chu T, Chen P, Beech W, Teter B, Tran T, Ubeda O, Ashe KH, Frautschy SA, Cole GM: Ibuprofen suppresses plaque pathology and inflammation in a mouse model for Alzheimer's disease. J Neurosci 2000 , 20:5709-5714

43. Yan Q, Zhang J, Liu H, Babu-Khan S, Vassar R, Biere AL, Citron M, Landreth G: Anti-inflammatory drug therapy alters $\beta$-amyloid processing and deposition in an animal model of Alzheimer's disease. J Neurosci 2003, 23:7504-7509.

44. Eriksen JL, Sagi SA, Smith TE, Weggen S, Das P, McLendon DC, Ozols W, Jessing KW, Zavitz KH, Koo EH, Golde TE: NSAIDs and enantiomers of flurbiprofen target $\gamma$-secretase and lower Aß42 in vivo. J Clin Invest 2003, 112:440-449.

45. Wilcock GK, Black SE, Hendrix SB, Zavitz KH, Swabb EA, Laughlin MA, Tarenflurbil Phase II Study Investigators: Efficacy and safety of tarenflurbil in mild to moderate Alzheimer's disease: a randomised phase II trial. Lancet Neurol 2008, 7:483-493.
46. Beher D, Clarke EE, Wrigley JDJ, Martin ACL, Nadin A, Churcher I, Shearman MS: Selected non-steroidal anti-inflammatroy drugs and their derivatives target $\gamma$-secretase at a novel site: evidence for an allosteric mechanism. J Biol Chem 2004, 279:43419-43426.

47. Green RC, Schneider LS, Amato DA, Beelen AP, Wilcock G, Swabb EA, Zavitz $\mathrm{KH}$, Tarenflurbil Phase III Study Group: Effect of tarenflurbil on cognitive decline and activities of daily living in patients with mild alzheimer disease: a randomized controlled trial. JAMA 2009, 302:2557-2564.

48. Oehlrich D, Bertholet DJ-C, Gijsen HJM: $\gamma$-secretase modulators as potential disease modifying anti-Alzheimer's drugs. J Med Chem 2011, 54:669-698.

49. Westerman MA, Cooper-Blacketer D, Mariash A, Kotilinek L, Kawarabayashi T, Younkin LH, Carlson GA, Younkin SG, Ashe KH: The relationship between $A \beta$ and memory in the Tg2576 mouse model of Alzheimer's disease. J Neurosci 2002, 22:1858-1867.

50. Kuo Y-M, Kokjohn TA, Beach TG, Sue LI, Brune D, Lopez JC, Kalback WM, Abramowski D, Sturchler-Pierrat C, Staufenbiel M, Roher AE: Comparative analysis of amyloid- $\beta$ chemical structure and amyloid plaque morphology of transgenic mouse and Alzheimer's disease brains. J Biol Chem 2001, 276:12991-12998.

51. Liu L, Orozco IJ, Planel E, Wen Y, Bretteville A, Krishnamurthy P, Wang L, Herman M, Figueroa H, Yu WH, Arancio O, Duff K: A transgenic rat that develops Alzheimer's disease-like amyloid pathology, deficits in synaptic plasticity and cognitive impairment. Neurobiol Dis 2008, 31:46-57.

52. Kim KS, Wen GY, Bancher C, Chen CMJ, Sapienza VJ, Hong H, Wisniewski HM: Detection and quantitation of amyloid B-peptide with 2 monoclonal antibodies. Neurosci Res Commun 1990, 7:113-122.

53. Gordon MN, Holcomb LA, Jantzen PT, DiCarlo G, Wilcock D, Boyett KW, Connor K, Melachrino J, O'Callaghan JP, Morgan D: Time course of the development of Alzheimer-like pathology in the doubly transgenic PS1 +APP mouse. Exp Neurol 2002, 173:183-195.

54. Shapiro G, Chesworth R: Tetrasubstituted benzenes.: PCT publication WO2009/086277; 2009.

55. Tesco G, Ginestroni A, Hiltunen M, Kim M, Dolios G, Hyman BT, Wang R, Berezovska O, Tanzi RE: APP substitutions V715F and L720P alter PS1 conformation and differentially affect $A \beta$ and AICD generation. J Neurochem 2005, 95:446-456.

56. Brewer GJ, Torricelli JR, Evege EK, Price PJ: Optimized survival of hippocampal neurons in B27-supplemented neurobasal ${ }^{\mathrm{TM}}$, a new serumfree medium combination. J Neurosci Res 1993, 35:567-576.

57. Bottenstein JE: Defined media for dissociated neural cultures. In Current Methods in Cellular Neurobiology. Edited by Barker JL, McKelvy JF. New York: John Wiley and Sons; 1983:107-130. Volume 4.

58. Miller DL, Potempska A, Mehta PD: Humoral immune responses to peptides derived from the $\beta$-amyloid peptide C-terminal sequence. Amyloid 2007, 14:39-50.

59. Portelius E, Tran AJ, Andreasson U, Pesson R, Brinkmalm G, Zetterberg H, Blennow K, Westman-Brinkmalm A: Characterization of amyloid $\beta$ peptides in cerebrospinal fluid by an automated immunoprecipitation procedure followed by mass spectrometry. J Proteome Res 2007, 6:4433-4439.

60. Serneels L, Dejaegere T, Craessaerts K, Horré K, Jorissen E, Tousseyn T, Hébert S, Coolen M, Martens G, Zwijsen A, Annaert W, Hartmann D, De Strooper B: Differential contribution of the three Aph1 genes to gammasecretase activity in vivo. Proc Natl Acad Sci USA 2005, 102:1719-1724.

61. Felsenstein KM, Hunihan LW, Roberts SB: Altered cleavage and secretion of a recombinant $\beta$-APP bearing the Swedish familial Alzheimer's disease mutation. Nat Genet 1994, 6:251-256.

62. Bentahir M, Nyabi O, Verhamme J, Tolia A, Katrien Horré K, Wiltfang J, Esselmann $H$, De Strooper B: Presenilin clinical mutations can affect $\gamma$-secretase activity by different mechanisms. J Neurochem 2006, 96:732-742.

63. Tanghe A, Termont A, Merchiers P, Schilling S, Demuth H-U, Scrocchi L, Van Leuven F, Griffioen G, Van Dooren T: Pathological hallmarks, clinical parallels, and value for drug testing in Alzheimer's disease of the APP [V717l] London transgenic mouse model. Int J Alzheimers Dis 2010, :pii 417314. doi:10.4061/2010/417314.

doi:10.1186/1750-1326-7-61

Cite this article as: Rogers et al:: Modulation of $\mathrm{Y}$-secretase by EVP0015962 reduces amyloid deposition and behavioral deficits in Tg2576 mice. Molecular Neurodegeneration 2012 7:61. 